\title{
A kinetic model for predicting the oxidative degradation of additive free polyethylene in bleach desinfected water
}

\author{
Aicha Mikdamª,b, Xavier Colin ${ }^{\mathrm{a}, *}$, Gaelle Minard ${ }^{\mathrm{a}}$, Noelle Billon ${ }^{\mathrm{b}}$, Romain Maurin ${ }^{\mathrm{c}}$ \\ a Arts et Métiers ParisTech, PIMM (UMR CNRS 8006), 151 Boulevard de L'Hôpital, 75013 Paris, France \\ b Mines ParisTech, PSL - Research University, CEMEF (UMR CNRS 7635), CS 10207, Rue Claude Daunesse, 06904 Sophia Antipolis Cedex, France \\ ${ }^{\mathrm{c}}$ EDF R \& D, Site des Renardières, Avenue des Renardières - Ecuelles, 77818 Moret-sur-Loing Cedex, France
}

Keywords:

Polyethylene

Sodium hypochlorite

Oxidation

Chain scissions

Kinetic modeling

\begin{abstract}
A B S T R A C T
The chemical interactions between additive free PE and bleach were investigated by FTIR spectrophotometry and viscosimetry in molten state after immersion (for a maximum duration of one hundred days) in bleach solutions maintained at a temperature of $60^{\circ} \mathrm{C}$, a free chlorine concentration of $100 \mathrm{ppm}$, and a pH $=4,5$ or 7 . It was found that the polymer undergoes a severe oxidation from the earliest days of exposure in a superficial layer of about $50-100 \mu \mathrm{m}$ thick, almost independent of the $\mathrm{pH}$ value. In this layer, oxidation leads to the formation and accumulation of various carbonyl products (mostly ketones and carboxylic acids) but also, after about 2-3 weeks of exposure, to a dramatic decrease in the average molar mass due to the large predominance of chain scissions over crosslinking. It was also found that the oxidation rate is maximum at $\mathrm{pH}=5$, and of the same order of magnitude at $\mathrm{pH}=4$ and 7 . Based on the equilibrium diagram giving access to the relative predominance of the three main chemical species as a function of the $\mathrm{pH}$ value of the bleach solution, it was assumed that oxidation is initiated by radical species coming firstly from hypochlorous acid $(\mathrm{ClOH})$ and secondarily from chlorine $\left(\mathrm{Cl}_{2}\right)$, given that hypochlorite ions $\left(\mathrm{ClO}^{-}\right)$are totally insoluble into the PE matrix. In addition, for explaining the surprisingly large value of the oxidized layer thickness despite the high reactivity of the involved radicals, it was assumed that $\mathrm{ClOH}$ and $\mathrm{Cl}_{2}$ do not decompose into radicals in the water phase, but migrate deeply into the PE matrix prior to dissociating into $\mathrm{Cl} \cdot$ and $\mathrm{HO} \cdot$ radicals and then, initiating a radical chain oxidation. The validity of the kinetic model derived from this scenario was successfully checked by comparing the numerical simulations with all the experimental data collected in this study. This model predicts the general trends of the oxidation kinetics and its dependence on the $\mathrm{pH}$ value, but also gives access to the transport properties of the chlorinated disinfectants and their radical species, and the rate constants of the radical attack.
\end{abstract}

\section{Introduction}

Steel pipes (with or without polymeric coating) are traditionally used for tertiary cooling circuits in nuclear power plants. Water is commonly disinfected by chlorinated reagents in order to control the microbiological growth and limit the deposit and development of shellfish and seaweed that might clog the circuit input. However, steel is sensitive to corrosion and water disinfectants are relatively strong oxidizers susceptible to accelerate corrosion. Therefore, in recent years, the nuclear industry has launched heavy testing campaigns for qualifying polymeric materials for this type of application, in particular polyethylene (PE), in view of using them in replacement of steel.

PE pipes are currently used for conveying drinking water under a pressure of a few bars since the early 1970s. There is an abundant literature on results of isobaric and isothermal ageing tests in pure distilled water at temperatures higher than typically $40{ }^{\circ} \mathrm{C}$ (see for instance references [1-3]). The construction of a single master curve by using adequate Arrhenius shift factors [2] allows extrapolating these results up to ambient temperature and thus, demonstrating that pipes perish always by brittle fracture with lifetimes exceeding typically 50 years in the domain of water pressures of practical interest.

In the past half century, considerable research efforts were accomplished for optimizing the polymer structure, at both macromolecular and morphological scales [4-10], but also the processing conditions [11] in view of improving the pipe durability. In the last two decades however, it was discovered that the water disinfectants do not only destroy the organic substances in water by oxidizing processes (among which radical processes play a key role), but also consume the

\footnotetext{
* Corresponding author.

E-mail address: xavier.colin@ensam.eu (X. Colin).
} 
stabilizing function of phenolic antioxidants and initiate a radical chain oxidation of the polymer matrix in the inner wall of pipes, thus leading to a significant reduction the pipe lifetime. These deleterious effects are especially pronounced when chlorine dioxide is used as a disinfectant [12-14], but measurable effects were also evidenced in the case of chlorine and bleach [15-21].

The chemistry of water disinfection is relatively well known. Both radical and ionic species (for instance, $\mathrm{ClO}^{-}$in the case of chlorine and bleach) have a strong oxidizing power. However, PE acts as a selective absorber because highly polar species such as ions are totally insoluble into this non-polar matrix. This characteristic was first discovered by Ravens [22] in the case of the poly(ethylene terephthalate) (PET) hydrolysis. PE is part of the less polar polymers: its dipolar moment is zero and its dielectric permittivity is 2.3 [23]. In contrast, radicals are more or less soluble into PE depending on their solubility parameter. As a result, three distinct scenarios can be considered for explaining the chemical attack of both phenolic antioxidants and PE matrix:

- S1) The disinfectant is itself a free radical in ground state which can migrate into PE. This is the case of chlorine dioxide $\left(\mathrm{ClO}_{2}\right)[12,13]$;

- S2) The disinfectant generates radicals in water, then these latter migrate into $\mathrm{PE}$;

- S3) The disinfectant itself, or a non-dissociated molecule formed from this disinfectant in water, migrates deeply into PE where it dissociates into radicals.

The identification of the reactive species and the determination of their respective concentration in the PE matrix remain an open issue, especially in the case of chlorine and bleach for which the two last scenarios S2 and S3 are conceivable. It is now well known that bleach solutions contain three main chemical species whose the relative proportions depend essentially on the $\mathrm{pH}$ value [24], as shown for instance at $25{ }^{\circ} \mathrm{C}$ in Fig. 1. These latter can be determined from the kinetic analysis of the two following chemical equilibria:

$\mathrm{Cl}_{2 \text { (aq) }}+2 \mathrm{H}_{2} \mathrm{O} \leftrightarrows \mathrm{ClOH}+\mathrm{Cl}^{-}+\mathrm{H}_{3} \mathrm{O}^{+}$

$\mathrm{ClOH}+2 \mathrm{H}_{2} \mathrm{O} \leftrightarrows \mathrm{ClO}^{-}+\mathrm{H}_{3} \mathrm{O}^{+}$

It comes:

$\%_{\mathrm{Cl}_{2}}=\frac{100 \times 10^{-\mathrm{pH}+\mathrm{pK}_{\mathrm{d}}}}{1+10^{-\mathrm{pH}+\mathrm{pK}_{\mathrm{d}}}+10^{\mathrm{pH}-\mathrm{pK}_{\mathrm{a}}}}$
$\%_{\mathrm{ClOH}}=\frac{100}{1+10^{-\mathrm{pH}^{\mathrm{pK}}} \mathrm{d}+10^{\mathrm{pH}^{-\mathrm{pK}_{\mathrm{a}}}}}$

$\%_{\mathrm{ClO}^{-}}=\frac{100 \times 10^{\mathrm{pH}-\mathrm{pK}}}{1+10^{-\mathrm{pH}+\mathrm{pK}_{\mathrm{d}}}+10^{\mathrm{pH}-\mathrm{pK}_{\mathrm{a}}}}$

The temperature dependence of the equilibrium constants $K_{d}$ and $K_{a}$ was reported in the literature $[25,26]$. Typically between 0 and $45{ }^{\circ} \mathrm{C}$, it can be written:

$\mathrm{pK}_{\mathrm{d}}=\frac{982798}{\mathrm{~T}^{2}}-\frac{5485.7}{\mathrm{~T}}+10.7484$

$\mathrm{pK}_{\mathrm{a}}=\frac{3000}{\mathrm{~T}}-10.0686+0.0253 \mathrm{~T}$

Since $K_{\mathrm{d}}$ and $\mathrm{K}_{\mathrm{a}}$ are very slowly decreasing functions of temperature, the chemical composition of bleach is almost insensitive to temperature. In fact, the chemical equilibria are very slightly shifted towards lower $\mathrm{pH}$ values when increasing the temperature. It can be thus concluded that chlorine $\left(\mathrm{Cl}_{2}\right)$, hypochlorous acid $(\mathrm{ClOH})$ and hypochlorite ion $\left(\mathrm{ClO}^{-}\right)$predominate respectively in highly acidic $(\mathrm{pH}<3)$, weakly acidic $(3<\mathrm{pH}<7.5)$ and basic media $(\mathrm{pH}>7.5)$, whatever the temperature. Moreover, the maximum yield of $\mathrm{ClOH}$ is reached at $\mathrm{pH}=5$.

Based on these observations, it is thus possible to select carefully $\mathrm{pH}$ conditions for identifying what chemical species are responsible for the polymer degradation, but also for deciding between the two possible scenarii S2 and S3.

According to Holst [27], when they coexist (at $\mathrm{pH}=7.5 \pm 1.5$ ), $\mathrm{ClOH}$ and $\mathrm{ClO}^{-}$would generate $\mathrm{ClO} \cdot$ and $\mathrm{HO} \cdot$ radicals in water:

$\mathrm{ClOH}+\mathrm{ClO}^{-} \rightarrow \mathrm{ClO}^{\circ}+\mathrm{Cl}^{-}+\mathrm{HO}^{\circ}$

$\mathrm{HO} \cdot+\mathrm{ClO}^{-} \rightarrow \mathrm{HO}^{-}+\mathrm{ClO}$.

$\mathrm{ClO}+\mathrm{ClO}^{-}+\mathrm{HO}^{-} \rightarrow 2 \mathrm{Cl}^{-}+\mathrm{O}_{2}+\mathrm{HO}$.

Thus, scenario S2 could be considered. This scenario was supported by some authors who effectively found a maximum degradation rate at $\mathrm{pH}=7$ for polyether-based polyurethane fibers [28], or at $\mathrm{pH}=8$ for polysulfone membranes [29-31].

On the contrary, for other authors $[18,20,32,33], \mathrm{Cl}_{2}$ and $\mathrm{ClOH}$ could directly dissociate into $\mathrm{Cl} \cdot$ and $\mathrm{HO}$ - radicals (presumably within the $\mathrm{PE}$ matrix) because $\mathrm{Cl}-\mathrm{Cl}$ and $\mathrm{Cl}-\mathrm{O}$ bonds are characterized by a very low dissociation energy (of respectively 242 and $247 \mathrm{~kJ} \mathrm{~mol}^{-1}$ [34]):

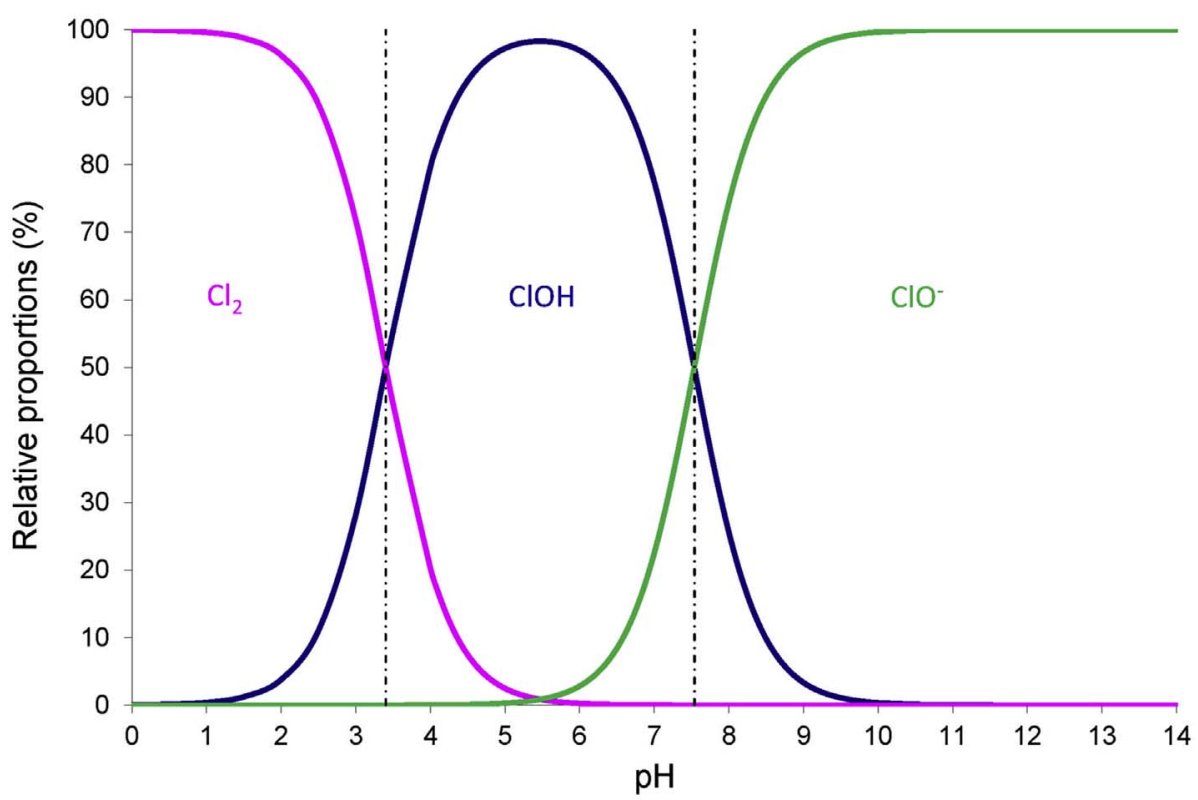

Fig. 1. Chemical composition of a bleach solution in function of the $\mathrm{pH}$ value at $25{ }^{\circ} \mathrm{C}$. 
$\mathrm{Cl}_{2} \rightarrow 2 \mathrm{Cl}$.

$\mathrm{ClOH} \rightarrow \mathrm{Cl} \cdot+\mathrm{HO} \cdot$

In this case, the degradation rate would be maximum at $\mathrm{pH}<7$ and scenario $\mathrm{S} 3$ could be envisaged.

Regardless the chosen scenario, it will remain to determine the relative proportion of each radical involved in the polymer degradation events. Since HO radicals are of the smallest molecular size, they have a high diffusivity into the PE matrix, presumably very close to that of water [35]. However, as they are also extremely reactive with respect to hydrocarbon substrates (typically more than $10^{10}$ times more reactive than $\mathrm{PO}_{2}$. radicals at $25{ }^{\circ} \mathrm{C}$ [36-38]), they should be scavenged into a sub-micrometric superficial layer of PE pipes. In contrast, chlorinated radicals $(\mathrm{ClO} \cdot$ and $\mathrm{Cl} \cdot$ ) should diffuse more slowly into the inner pipe wall because of their larger molecular size, but they should be also much less reactive than $\mathrm{HO}$ - radicals. In fact, it is expected that their reactivity ranks in the following order:

$\mathrm{HO}^{*} \gg \mathrm{ClO}^{*} \gg \mathrm{Cl}^{*}$

In a first approach, the depth $\mathrm{L}$ of penetration of a radical species can be estimated from a simple scaling law [39]:

$\mathrm{L} \approx\left(\frac{\mathrm{D}}{\mathrm{K}}\right)^{1 / 2}$

where $\mathrm{D}$ is the diffusion coefficient and $\mathrm{K}$ the first-order constant for the consumption of the diffusing species by the chemical reaction with the polymer.

As an example, this equation can be used to compare $\mathrm{HO} \cdot$ and $\mathrm{ClO}$. radicals:

$\frac{\mathrm{L}_{\mathrm{HO}}}{\mathrm{L}_{\mathrm{ClO}}}=\left(\frac{\mathrm{D}_{\mathrm{HO}}}{\mathrm{D}_{\mathrm{ClO}}} \cdot \frac{\mathrm{K}_{\mathrm{ClO}}}{\mathrm{K}_{\mathrm{HO}}}\right)^{1 / 2}$

The diffusion coefficients of both radicals into the PE matrix are not known, but by analogy with more common vapors and gases of very close molecular size, for instance $\mathrm{H}_{2} \mathrm{O}$ [35] and $\mathrm{CO}_{2}$ [23], it can be written:

$1<\frac{\mathrm{D}_{\mathrm{HO}}}{\mathrm{D}_{\mathrm{ClO}}}<10$

So that, presumably:

$\frac{\mathrm{L}_{\mathrm{HO}}}{\mathrm{L}_{\mathrm{ClO}}} \approx 10^{-3}-10^{-2}$

Chlorinated radicals are thus expected to penetrate more deeply into the inner wall of pipes. The order of magnitude of the depth of this radical attack should also allow us to decide between scenarii S2 and S3.

The objectives of the present article are twofold. The first objective is to evidence and analyze by conventional laboratory techniques the chemical interactions between additive free $\mathrm{PE}$ and bleach in view of proposing a general degradation mechanism. Since $\mathrm{ClOH}$ is often considered as the main source of radicals in the literature [27-33], three distinct $\mathrm{pH}$ values, corresponding to the maximum yield $(\mathrm{pH}=5)$ and lower but equivalent yields of $\mathrm{ClOH}(\mathrm{pH}=4$ and 7), will be investigated. The two last values are necessary to see if $\mathrm{Cl}_{2}$ may be a secondary source of radicals. If so, the degradation rate will be less reduced in acidic $(\mathrm{pH}=4)$ than in neutral medium $(\mathrm{pH}=7)$. In these exposure conditions, two aging indicators will be used for deciding between scenarii S2 and S3: the oxidation rate and the thickness of the oxidation layer. The second objective is to derive a kinetic model from the degradation mechanism and to check its validity by comparing the numerical simulations with all the experimental data collected in this study.

\section{Experimental}

\subsection{Materials}

An unstabilized and unfilled PE powder was supplied by Borealis Company for this study. PE films of thicknesses ranging between 150 and $350 \mu \mathrm{m}$ were formed by compression molding with a Gibrite laboratory press under a pressure of $3 \mathrm{MPa}$ for $2 \mathrm{~min}$ at $180{ }^{\circ} \mathrm{C}$. After demolding, the films were characterized by conventional laboratory techniques.

The FTIR spectrophotometry was used in a transmission mode to check that the molding conditions had avoided a premature oxidation of the films. No trace of oxidation was detected after processing and it was necessary to expose the PE films for long periods at moderate temperatures to finally see the appearance of oxidation products. Typical values of induction period of unoxidized PE [47] were found: $27 \mathrm{~h}$ at $120{ }^{\circ} \mathrm{C}$ and $125 \mathrm{~h}$ at $100{ }^{\circ} \mathrm{C}$ in air.

The main characteristics of the PE films are: melting point $\mathrm{T}_{\mathrm{m} 0}=128.3{ }^{\circ} \mathrm{C}$, crystallinity ratio $\mathrm{X}_{\mathrm{C} 0}=51 \%$, density $\rho_{0}=0.934 \mathrm{~g} \mathrm{~cm}^{-3}$, weight average molecular masses $\mathrm{M}_{\mathrm{w} 0}=105 \pm 5 \mathrm{~kg} \mathrm{~mol}^{-1}$ and polydispersity index: $\mathrm{I}_{\mathrm{p} 0}=2.5$.

\subsection{Ageing conditions}

PE films were immersed in bleach solutions in glass carboys whose the outer surface was painted with a metal color for avoiding undesired effects of UV radiations throughout the duration of ageing tests. The bleach solutions were maintained at a temperature of $60 \pm 1{ }^{\circ} \mathrm{C}$ in airventilated ovens, and weekly controlled to be re-adjusted (if necessary) at nominal values of free chlorine concentration $[\text { free } \mathrm{Cl}]_{\mathrm{W}}=100 \mathrm{ppm}$ (i.e. $100 \mathrm{mg} \mathrm{L}^{-1}$ ) and $\mathrm{pH}=4,5$ or 7 . These solutions were prepared in advance by diluting with pure distilled water and adding a few drops of hydrochloric acid in a highly concentrated $\left(38 \mathrm{~g} \mathrm{~L}^{-1}\right)$ and very basic $(\mathrm{pH}=11.5)$ commercial solution supplied by Sigma-Aldrich. The corresponding concentrations of the three main chemical species (i.e. $\mathrm{Cl}_{2}, \mathrm{ClOH}$, and $\mathrm{ClO}^{-}$) in water were simply deduced as follows:

$\left[\mathrm{Cl}_{2}\right]_{\mathrm{W}}=[\text { free } \mathrm{Cl}]_{\mathrm{W}} \cdot \% \mathrm{Cl}_{2}$

$[\mathrm{ClOH}]_{\mathrm{W}}=[\text { free } \mathrm{Cl}]_{\mathrm{W}} \cdot \%_{\mathrm{ClOH}}$

$\left[\mathrm{ClO}^{-}\right]_{\mathrm{W}}=[\text { free } \mathrm{Cl}]_{\mathrm{W}} \cdot \%_{\mathrm{ClO}^{-}}$

where $\%_{i}$ is the relative proportion of the chlorinated species $i$ under consideration depending essentially on the $\mathrm{pH}$ value (see Fig. 1).

\subsection{Experimental methods}

At defined immersion durations, PE films were removed from the bleach solutions and dried at room temperature in a desiccator containing silica-gel. After complete drying, they were characterized by conventional laboratory techniques in order to determine the resulting changes at both molecular and macromolecular scales.

\subsection{FTIR analysis}

The course of oxidation was monitored by FTIR spectrophotometry according to two different but complementary methods. On one hand, IR spectra across the entire film thickness were determined in a transmittance mode within the $400-4000 \mathrm{~cm}^{-1}$ range (with a minimal resolution of $4 \mathrm{~cm}^{-1}$ ) with a Perkin-Elmer Frontier device. The comparison between the IR spectra obtained for virgin and oxidized PE films (Figs. 2-4) revealed the development of two broad and intense absorption bands within the $3150-3700 \mathrm{~cm}^{-1}$ and $1680-1780 \mathrm{~cm}^{-1}$ ranges, whatever the $\mathrm{pH}$ value. These bands were respectively assigned to the stretching vibrations of $\mathrm{O}-\mathrm{H}$ and $\mathrm{C}=\mathrm{O}$ bonds of a large variety of hydroxyl and carbonyl compounds. However, since the latter is 

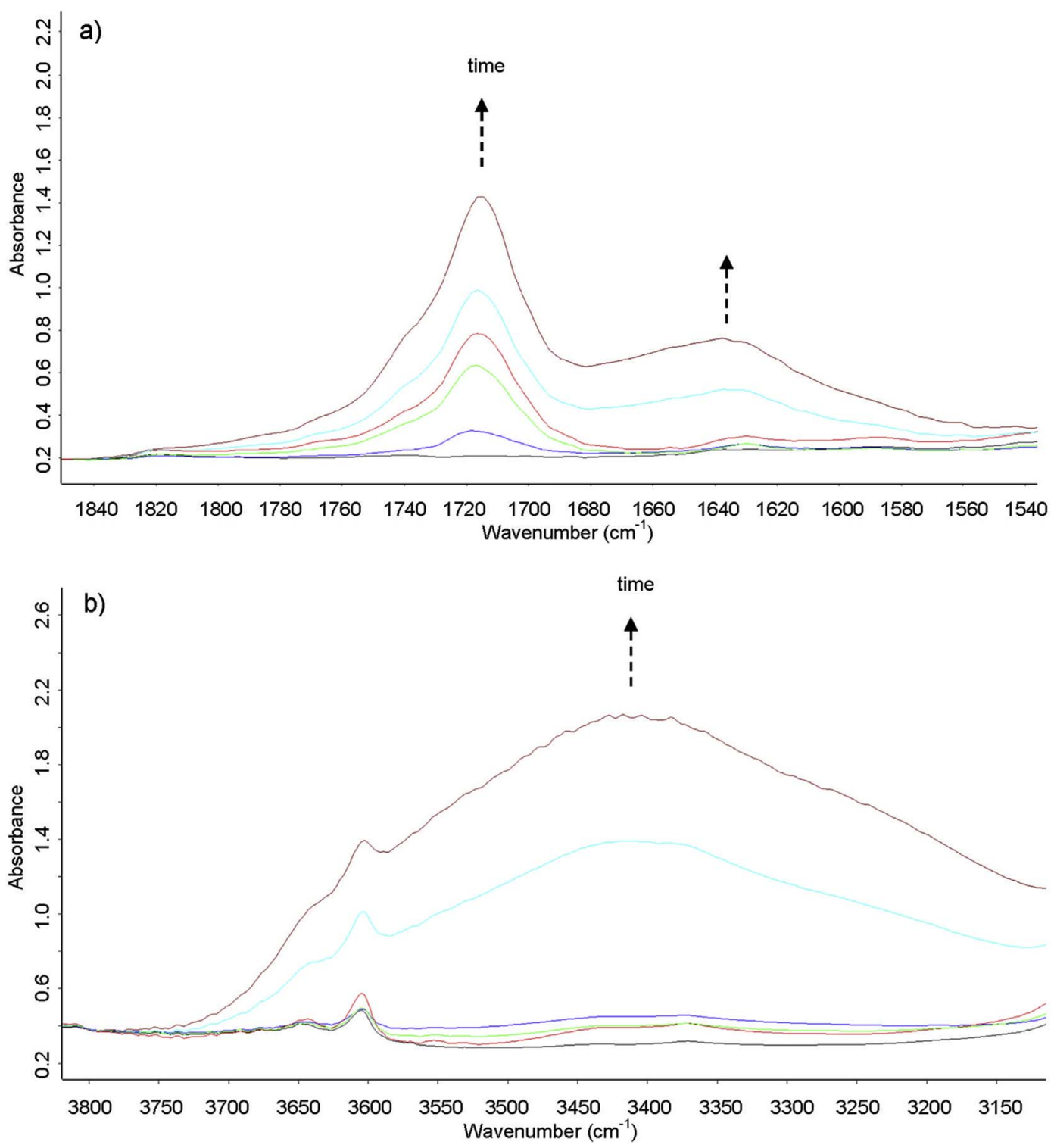

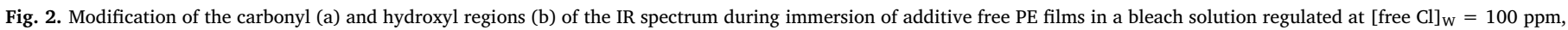
$\mathrm{T}=60^{\circ} \mathrm{C}$ and $\mathrm{pH}=4$.

centered at $1715 \mathrm{~cm}^{-1}$, it was concluded that carbonyls are mainly composed of ketones and carboxylic acids [40]. The carbonyl concentration across the entire PE film thickness $[\mathrm{CO}]_{\text {global }}$ was then calculated from the absorbance Abs at $1715 \mathrm{~cm}^{-1}$ by using the classical Beer-Lambert's law and taking a coefficient of molar extinction of $\varepsilon=300 \mathrm{~L} \mathrm{~mol}^{-1} \cdot \mathrm{cm}^{-1}[40]$ :

$[\mathrm{CO}]=\frac{\mathrm{Abs}}{\mathrm{ep} \cdot \varepsilon}$

where ep is the sample thickness.

In addition, in some ageing cases (see for instance Fig. 4), it was clearly observed the development of a third broad, but much less intense, absorption band within the $1560-1680 \mathrm{~cm}^{-1}$ range. This band was attributed to the stretching vibration of the $\mathrm{C}=\mathrm{O}$ bond of carboxylate ions $\mathrm{COO}^{-} \mathrm{M}^{+}$, presumably sodium carboxylates $\mathrm{COO}^{-} \mathrm{Na}^{+}$ $[41,42]$ resulting from the partial conversion of carboxylic acids by sodium hypochlorite according to the following reaction [43].

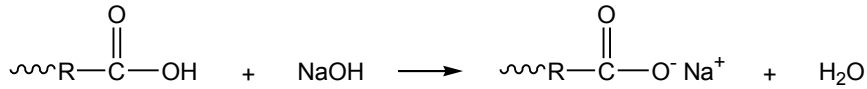

However, since carboxylate ions never exceed $10 \mathrm{~mol} \%$ of all the carbonyl compounds, their formation was neglected thereafter.

On the other hand, some PE films were cut in the thickness direction and embedded in a commercial epoxy-amine resin which was crosslinked for $12 \mathrm{~h}$ under primary vacuum at room temperature. Then, film cross-sections were polished with silicon carbide abrasive papers of decreasing particle size (typically from 80 to 2400 granulometry) before being examined by FTIR microscopy. IR spectra were determined every $1.56 \mu \mathrm{m}$ throughout the film thickness in an Attenuated Total Reflectance (ATR) mode within the $750-4000 \mathrm{~cm}^{-1}$ range (with a minimal resolution of $2 \mathrm{~cm}^{-1}$ ) with a Perkin-Elmer Spotlight 300 device equipped with a germanium crystal. Oxidation profiles were then calculated from the carbonyl absorbance Abs measured at $1715 \mathrm{~cm}^{-1}$ as described above (Equation (14)). Each profile was validated by checking that the sum of the local concentrations along the PE film thickness $[\mathrm{CO}]$ gives access to an average concentration $[\mathrm{CO}]_{\text {global }}$ very close to the experimental value measured by the first FTIR method.

\subsection{Viscosimetry}

The consequences of oxidation on the PE macromolecular structure 

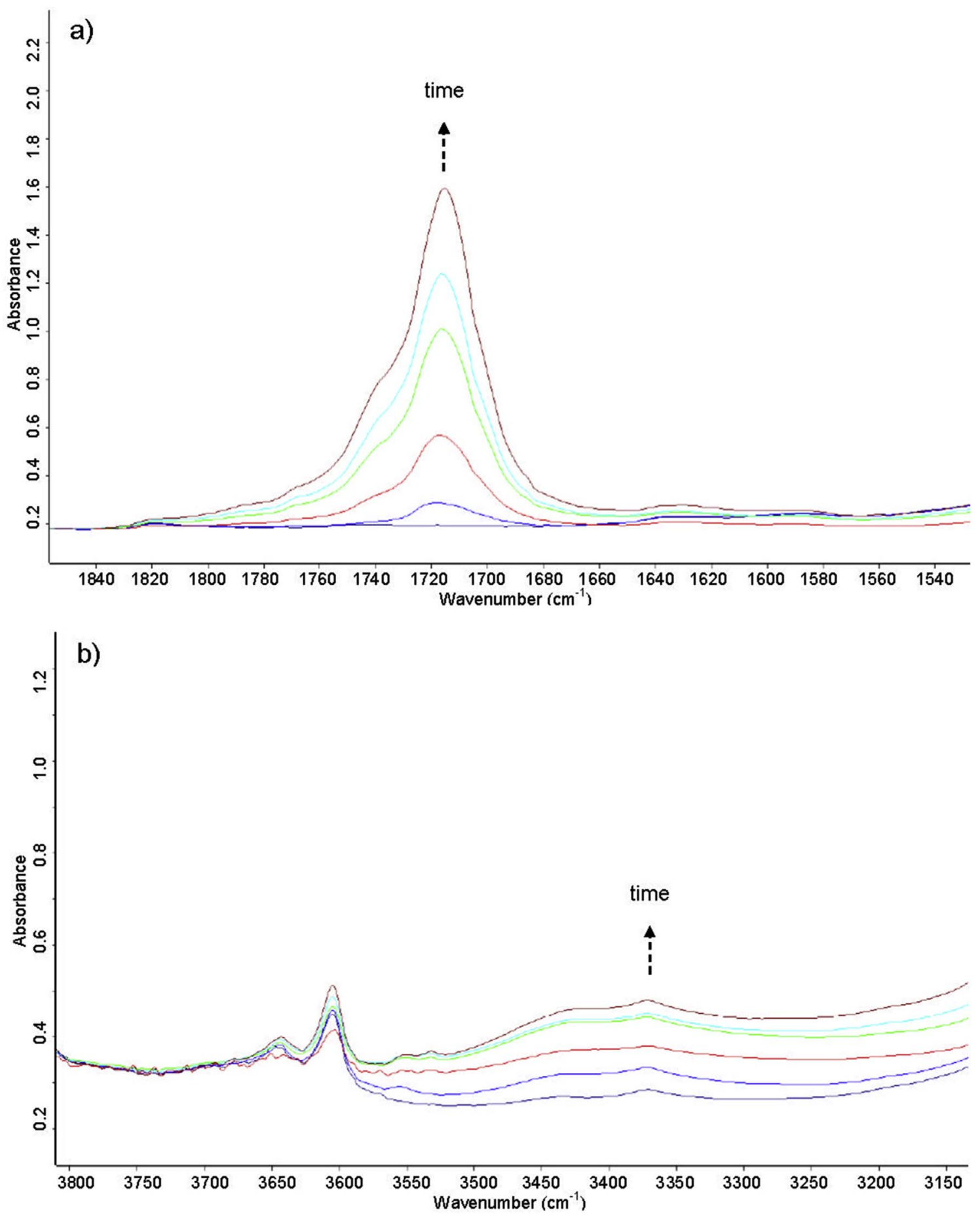

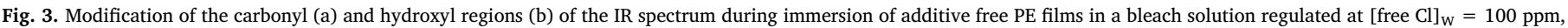
$\mathrm{T}=60^{\circ} \mathrm{C}$ and $\mathrm{pH}=5$.

were determined by viscosimetry in molten state (typically at $160{ }^{\circ} \mathrm{C}$ ) in inert atmosphere (nitrogen) with a TA Instruments ARES device equipped with a coaxial and parallel plate geometry. The plate diameter was chosen at $25 \mathrm{~mm}$ and the gap between plates was fixed at $1 \mathrm{~mm}$. Sweep angular frequency experiments were performed between 0.1 and $100 \mathrm{rad} \mathrm{s}^{-1}$ with a strain amplitude of $5 \%$ on stacks of about ten PE films. These experiments revealed that the rheological behavior of PE is Newtonian in the low frequency range, typically for $\omega \leq 1 \mathrm{rad} \mathrm{s}^{-1}$, before and after ageing (Fig. 5). In addition, it was found that the Newtonian viscosity $\eta$ varies non-monotonically with exposure time, whatever the $\mathrm{pH}$ value. After an initial period of about 2 or 3 weeks, during which it remains almost constant or increases very slowly, $\eta$ decreases catastrophically with exposure time, indicating that PE undergoes a largely predominant chain scission process. Although their progressive branching cannot be totally excluded, it was concluded that oxidation leads mainly to a progressive shortening of the polymer chains.

The resulting changes in the weight average molar mass $M_{W}$ global were determined by using the classical Bueche's equation $[44,45]$ :

$\eta=\mathrm{K} \cdot \mathrm{M}_{\mathrm{w}}^{3.4}$

where $\mathrm{K}$ is a constant depending only on molecular structure and 

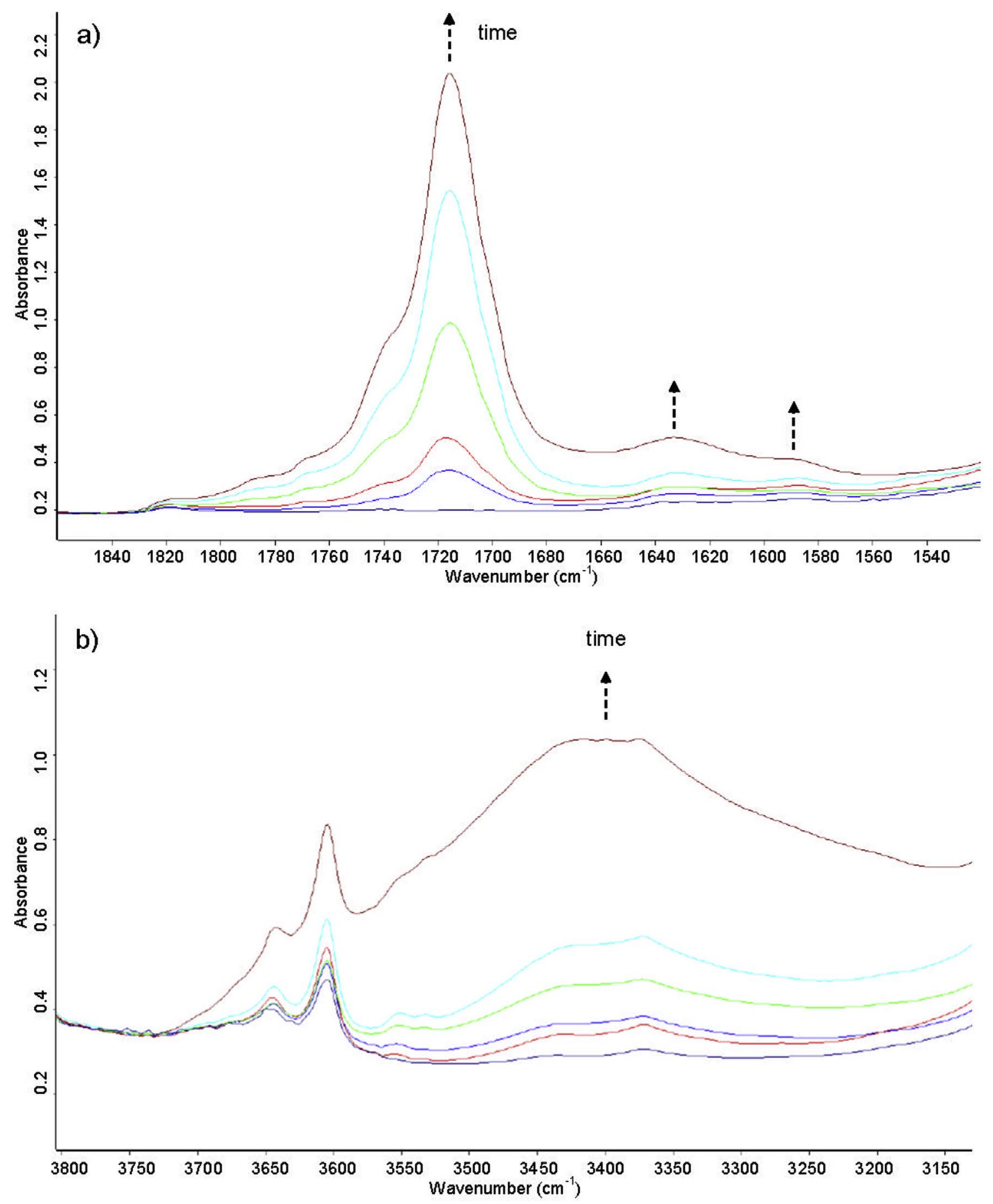

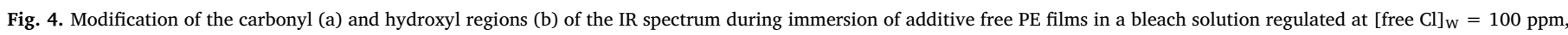
$\mathrm{T}=60{ }^{\circ} \mathrm{C}$ and $\mathrm{pH}=7$.

temperature. $\mathrm{K}$ was preliminary determined from a series of linear PE calibrants of perfectly known distribution of molar mass. It was found that $\mathrm{K}=2.46 \times 10^{-4} \mathrm{~Pa} \mathrm{~mol}^{3.4} \cdot \mathrm{kg}^{-3.4}$ for PE at $160{ }^{\circ} \mathrm{C}$.

\section{Results and discussion}

\subsection{Experimental results}

The changes in the average carbonyl concentration $[\mathrm{CO}]_{\text {global }}$ and weight average molar mass $\mathrm{M}_{\mathrm{W}}$ global of PE films are reported in Fig. 6 for all the exposure conditions under study. It appears clearly that the polymer undergoes a severe oxidation from the earliest days of exposure, but the average oxidation rate is faster at $\mathrm{pH}=5$ than at $\mathrm{pH}=4$ and 7. In addition, the kinetics curves reported at $\mathrm{pH}=4$ and 7 superimpose perfectly (if taking into account the measurement uncertainties). Based on the equilibrium diagram of Fig. 1, it can be concluded that oxidation is initiated by radical species coming mainly from $\mathrm{ClOH}$, the eventual contribution of $\mathrm{Cl}_{2}$ being clearly insufficient to be detectable. In addition, based on the mechanisms proposed in the literature $[18,20,27,32,33]$, it can be concluded that these radicals are formed according to scenario S3.

Examples of oxidation profiles determined after different immersion durations of PE films in bleach solutions are reported in Figs. 7 and 8. It is found that the radical attack operates in a superficial layer of about 

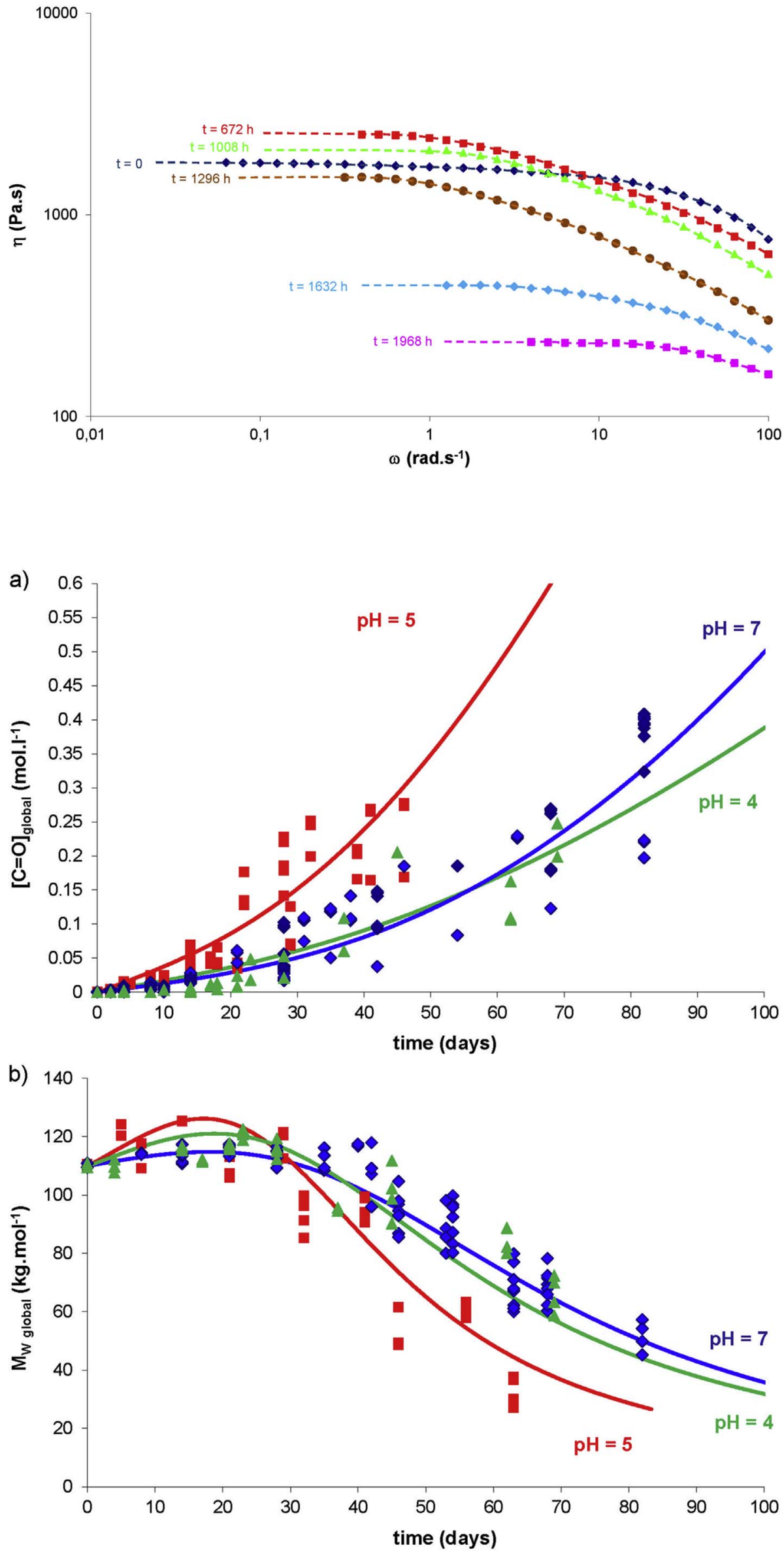

Fig. 5. Melt viscosity at $160{ }^{\circ} \mathrm{C}$ versus angular frequency after immersion of additive free PE films in a bleach solution regulated at $[\text { free } \mathrm{Cl}]_{\mathrm{W}}=100 \mathrm{ppm}, \mathrm{T}=60{ }^{\circ} \mathrm{C}$ and $\mathrm{pH}=7$.

Fig. 6. Kinetic curves of average carbonyl concentration (a) and weight average molar mass (b) during immersion of additive free PE films in bleach solutions regulated at [free $\mathrm{Cl}]_{\mathrm{W}}=100 \mathrm{ppm}, \mathrm{T}=60{ }^{\circ} \mathrm{C}$ and $\mathrm{pH}=4,5$ or 7. Comparison between experimental data (symbols) and kinetic modeling (solid lines). 


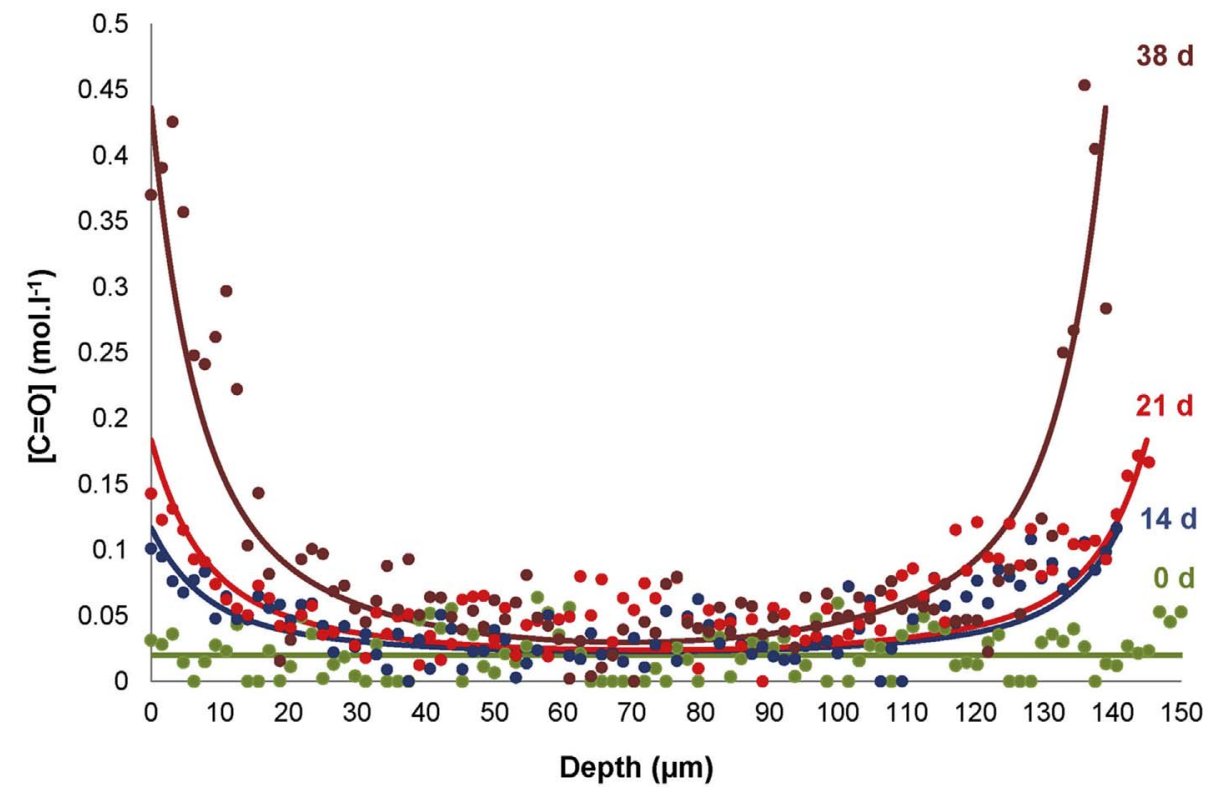

Fig. 7. Development of oxidation profiles in additive free PE films during their immersion (in days) in a bleach solution regulated at $[\text { free } \mathrm{Cl}]_{\mathrm{W}}=100 \mathrm{ppm}, \mathrm{T}=60{ }^{\circ} \mathrm{C}$ and $\mathrm{pH}=7$. Comparison between experimental data (symbols) and kinetic modeling (solid lines).
50-100 $\mu \mathrm{m}$ thick, almost independent of the $\mathrm{pH}$ value. This high thickness value also supports scenario S3. However, it appears that the general shape of the oxidation profiles depends on the $\mathrm{pH}$ value (Fig. 8). Indeed, these profiles are clearly in chain-shape in neutral medium, indicating that the oxidation kinetics is of the first-order as demonstrated in Ref. [39]. In addition, they are composed of a horizontal plateau (of about $30 \mu \mathrm{m}$ length) in the most superficial part of the oxidized layer in acidic media. This plateau presumably results from the presence of a secondary source of radicals, in this case $\mathrm{Cl}_{2}$, leading to a significant increase in the local oxidation rate and consequently, to a change of the local oxidation kinetics. In the most superficial part of the oxidized layer, the oxidation kinetics is obviously of the zero-order [39].

Based on these experimental observations, the following causal chain can be proposed for explaining both the initiation of oxidation by bleach and the development of oxidation profiles in additive free PE, whatever the $\mathrm{pH}$ value:

Formation of $\mathrm{Cl}_{2}, \mathrm{ClOH}$ and $\mathrm{ClO}^{-}$in the water phase $\rightarrow$ Migration of $\mathrm{Cl}_{2}$ and $\mathrm{ClOH}$ into the $\mathrm{PE}$ sample $\rightarrow$ Dissociation of $\mathrm{Cl}_{2}$ and $\mathrm{ClOH}$ into $\mathrm{Cl}$ - and $\mathrm{HO}$ - radicals $\rightarrow$ Radical attack of the PE matrix initiating its oxidation.

\subsection{Kinetic modeling}

This causal chain was introduced into the closed-loop mechanistic scheme developed during the two last decades in our laboratory for predicting other cases of PE oxidation at low temperature $[12,13,46-48]$. Then, a kinetic model was derived from this new mechanistic scheme by applying the classical rules of the chemical kinetics. The Fick's second law was directly introduced into this system of 14 differential equations in order to establish a strong coupling between the diffusion of all the molecular reagents (i.e. $\mathrm{Cl}_{2}, \mathrm{ClOH}, \mathrm{Cl} \cdot, \mathrm{HO} \cdot$ and $\mathrm{O}_{2}$ ) and their consumption by the chemical reaction. All these theoretical tools are detailed in Appendix A.

The kinetic model contains 27 parameters, consisting in boundary conditions, rate constants, chemical yields and diffusion coefficients, of which many have been already determined in previous studies $[12,13,46-48]$. Their values at $60^{\circ} \mathrm{C}$ are recalled in Table 1 .

Finally, only 12 parameters are unknown, all being relative to chlorinated disinfectants $\left(\mathrm{Cl}_{2}\right.$ and $\left.\mathrm{ClOH}\right)$ and their radical species $(\mathrm{Cl}$. and $\mathrm{HO} \cdot$ ). The following procedure was applied for their determination: a) An indirect approach based on structure/solubility relationships was used to access the value of the equilibrium concentration of $\mathrm{Cl}_{2}$. This approach, which had been already applied to $\mathrm{ClO}_{2}$ in a previous study [12], is detailed in Appendix B. It leads to:

$\left[\mathrm{Cl}_{2}\right]_{\mathrm{S}}=4.7 \times 10^{2}\left(1-\mathrm{X}_{\mathrm{C}}\right)\left[\mathrm{Cl}_{2}\right]_{\mathrm{w}} \exp \left(-\frac{19130}{\mathrm{RT}}\right)$

where $\mathrm{X}_{\mathrm{C}}$ is the PE crystallinity and $\left[\mathrm{Cl}_{2}\right]_{\mathrm{W}}$ is the concentration of $\mathrm{Cl}_{2}$ in water, depending mainly on the $\mathrm{pH}$ value (see Equation (11)).

Unfortunately, it cannot be applied to $\mathrm{ClOH}$ due to the total ignorance of some key characteristics, in particular its vaporization enthalpy. Since this chlorinated species contains a hydroxyl group able of establishing strong molecular interactions (i.e. hydrogen bonds) with polar side groups along the polymer chain, it was considered that it behaves like $\mathrm{H}_{2} \mathrm{O}$. Thus, its equilibrium concentration was deduced from water sorption experiments reported in the literature between 25 and $60{ }^{\circ} \mathrm{C}$ for ldPE [35]:

$\left[\mathrm{H}_{2} \mathrm{O}\right]_{\mathrm{S}}=3.8 \times 10^{3} \exp \left(-\frac{37600}{\mathrm{RT}}\right)$

The introduction of $\mathrm{X}_{\mathrm{C}}$ and $[\mathrm{ClOH}]_{\mathrm{W}}$ in this equation leads finally to:

$[\mathrm{ClOH}]_{\mathrm{S}}=5.1 \times 10^{-3}\left(1-\mathrm{X}_{\mathrm{C}}\right)[\mathrm{ClOH}]_{\mathrm{W}} \exp \left(-\frac{37600}{\mathrm{RT}}\right)$

b) The order of magnitude of the rate constant of the polymer attack by $\mathrm{HO}$. radicals was directly taken in the literature: $\mathrm{k}_{1 \mathrm{~h}}=10^{9} \mathrm{~L} \mathrm{~mol}^{-1} \cdot \mathrm{s}^{-1}$ [36-38]. In a first approach, the temperature variation of this rate constant was neglected owing to its very low activation energy $\left(E_{1 \mathrm{~h}}=1-10 \mathrm{~kJ} \mathrm{~mol}^{-1}\right)$ [49]. In addition, since HO. radicals and $\mathrm{H}_{2} \mathrm{O}$ are almost of the same molecular size, it was assumed that their diffusion coefficients into the PE matrix are also very close and thus, obey the following Arrhenius law [35]:

$\mathrm{D}_{\mathrm{HO}} \approx \mathrm{D}_{\mathrm{H}_{2} \mathrm{O}}=2.9 \times 10^{-4} \exp \left(-\frac{37600}{\mathrm{RT}}\right)$

Finally, the rate constant of addition of $\mathrm{HO} \cdot$ radicals onto $\mathrm{P} \cdot$ radicals $\left(\mathrm{k}_{7 \mathrm{~h}}\right)$ was determined by adjusting as closely as possible the experimental results obtained for PE films immerged in hydrogen peroxide solutions. Indeed, it has been shown in the literature that $\mathrm{H}_{2} \mathrm{O}_{2}$ is an efficient initiator of radical chain oxidation in polyolefins, leading to a predominant chain scission process and thus, to a catastrophic decrease in the molecular mass [59]. The kinetic model used for this identification was established on the same principles as for the bleach 


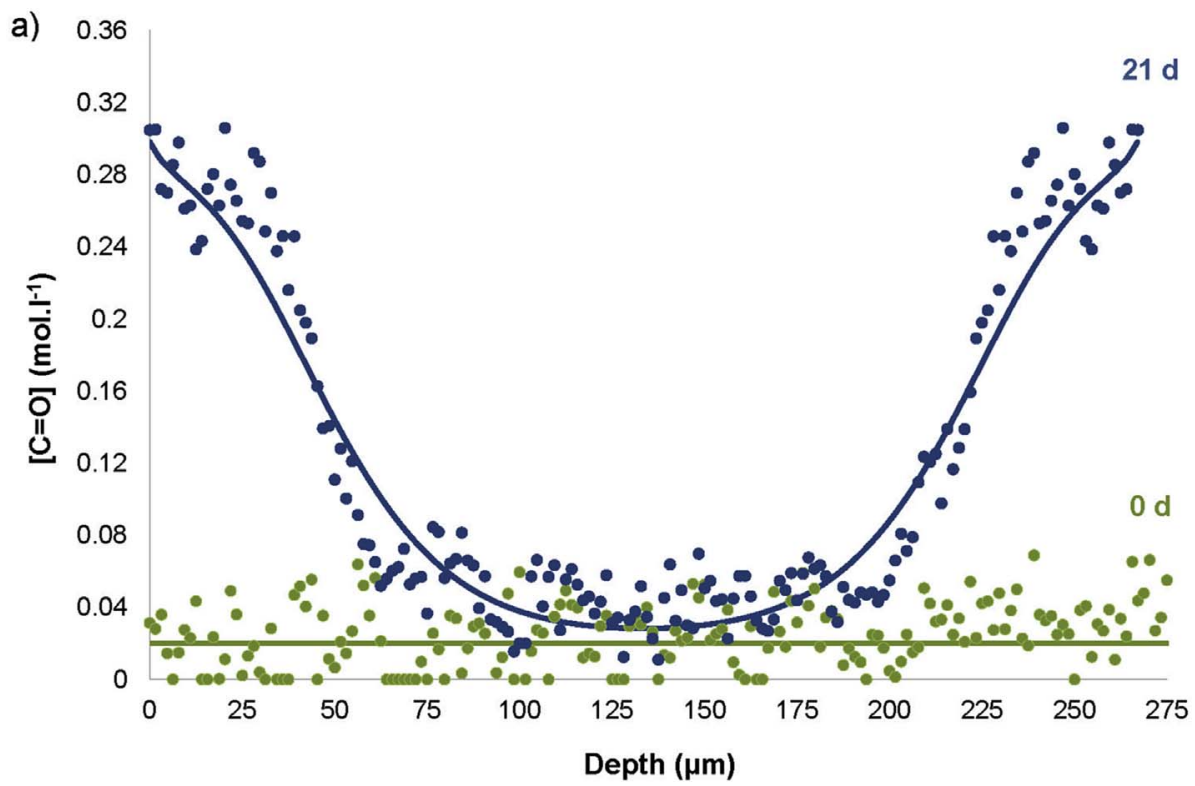

Fig. 8. Effect of $\mathrm{pH}$ on oxidation profiles in additive free $\mathrm{PE}$ films after 21 days of immersion in bleach solutions regulated at $[\text { free } \mathrm{Cl}]_{\mathrm{W}}=100 \mathrm{ppm}, \mathrm{T}=60{ }^{\circ} \mathrm{C}$ and $\mathrm{pH}=5$ (a) and $\mathrm{pH}=7$ (b). Comparison between experimental data (symbols) and kinetic modeling (solid lines).

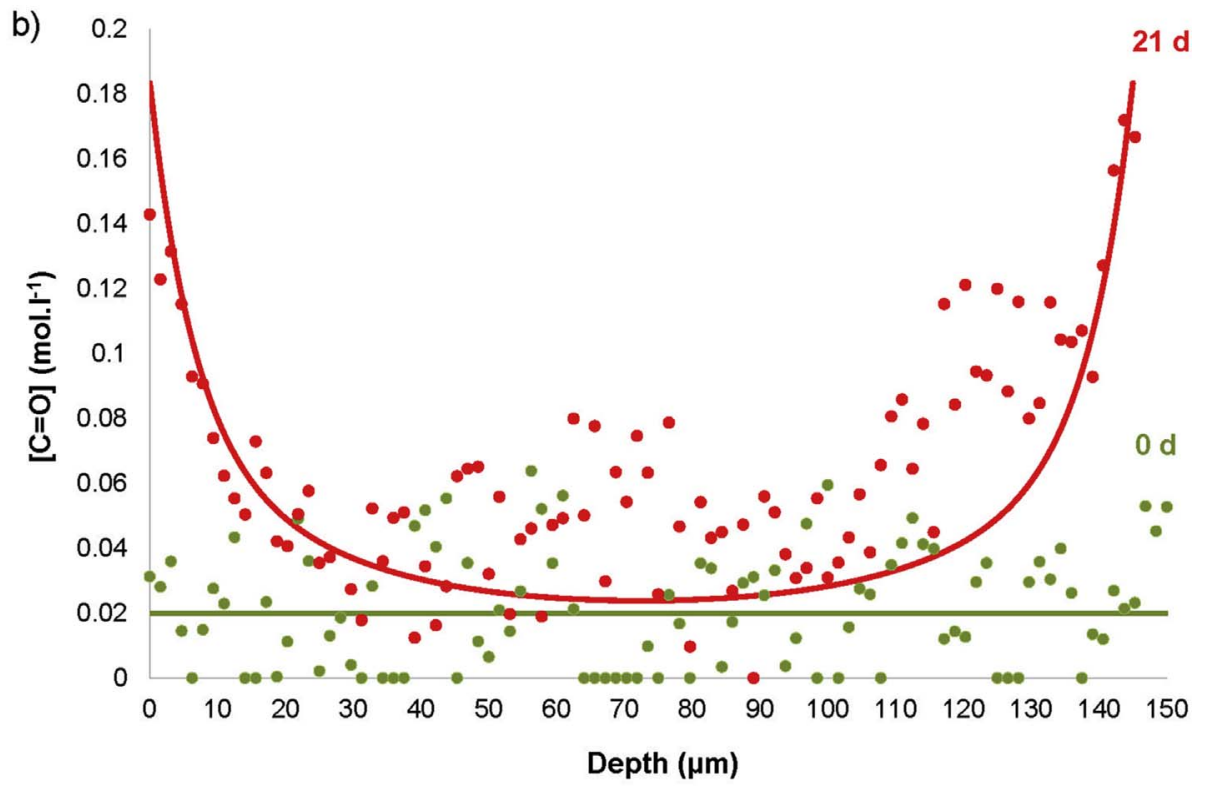

Table 1

Values at $60{ }^{\circ} \mathrm{C}$ of parameters used for modeling the thermal oxidation of PE.

\begin{tabular}{lll}
\hline Kinetic parameter & Value at $60^{\circ} \mathrm{C}$ & Unity \\
\hline$k_{1 \mathrm{u}}$ & $9.1 \times 10^{-10}$ & $\mathrm{~s}$ \\
$\mathrm{k}_{1 \mathrm{~b}}$ & $9.7 \times 10^{-8}$ & $\mathrm{~L} \cdot \mathrm{mol}^{-1} \cdot \mathrm{s}^{-1}$ \\
$\mathrm{k}_{2}$ & $10^{8}$ & $\mathrm{~L} \cdot \mathrm{mol}^{-1} \cdot \mathrm{s}^{-1}$ \\
$\mathrm{k}_{3}$ & $5.4 \times 10^{-2}$ & $\mathrm{~L} \cdot \mathrm{mol}^{-1} \cdot \mathrm{s}^{-1}$ \\
$\mathrm{k}_{4}$ & $8.0 \times 10^{11}$ & $\mathrm{~L} \cdot \mathrm{mol}^{-1} \cdot \mathrm{s}^{-1}$ \\
$\mathrm{k}_{5}$ & $1.8 \times 10^{11}$ & $\mathrm{~L} \cdot \mathrm{mol}^{-1} \cdot \mathrm{s}^{-1}$ \\
$\mathrm{k}_{6 \mathrm{a}}$ & $1.4 \times 10^{7}$ & $\mathrm{~L} \cdot \mathrm{mol}^{-1} \cdot \mathrm{s}^{-1}$ \\
$\mathrm{k}_{6 \mathrm{~b}}$ & $2.0 \times 10^{6}$ & $\mathrm{~s}$ \\
$\mathrm{k}_{6 \mathrm{c}}$ & $2.0 \times 10^{5}$ & $\mathrm{~s}$ \\
$\mathrm{k}_{6 \mathrm{~d}}$ & $9.0 \times 10^{6}$ & $\mathrm{~s}$ \\
$\gamma_{\mathrm{CO}}$ & 100 & $\%$ \\
$\gamma_{\mathrm{S}}$ & 41 & $\%$ \\
$\gamma_{4}$ & 50 & $\%$ \\
$\gamma_{5}$ & 1.1 & $\%$ \\
$D_{\mathrm{O} 2}$ & $1.4 \times 10^{-10}$ & $\mathrm{~m} \cdot \mathrm{s}^{-1}$ \\
\hline
\end{tabular}

solutions, i.e. from the following causal chain:

Migration of $\mathrm{H}_{2} \mathrm{O}_{2}$ into the $\mathrm{PE}$ sample $\rightarrow$ Dissociation of $\mathrm{H}_{2} \mathrm{O}_{2}$ into $\mathrm{HO} \cdot$ radicals $\rightarrow$ Radical attack of the PE matrix initiating its oxidation.

This model is detailed in Appendix C. For the same reasons mentioned for HO radicals, Equations (18) and (19) could be used for proposing a first set of values for the transport properties of $\mathrm{H}_{2} \mathrm{O}_{2}$ into the PE matrix. However, it is noteworthy that $\mathrm{H}_{2} \mathrm{O}_{2}$ is capable of establishing two hydrogen bonds (against only one for $\mathrm{H}_{2} \mathrm{O}$ ) with polar side groups. Thus, its equilibrium concentration is expected to be slightly higher while, according to structure/water permeability relationships [60], its diffusion coefficient should be somewhat lower than for water. Fortunately, $\left[\mathrm{H}_{2} \mathrm{O}_{2}\right]_{S}$ was reported in the literature for a ldPE sample immerged in a highly concentrated hydrogen peroxide solution at $\mathrm{T}=35^{\circ} \mathrm{C}[61]$ :

$\left[\mathrm{H}_{2} \mathrm{O}_{2}\right]_{\mathrm{S}}=1.1 \times 10^{-8}\left(1-\mathrm{X}_{\mathrm{C}}\right)\left[\mathrm{H}_{2} \mathrm{O}_{2}\right]_{\mathrm{W}}$

If $\mathrm{X}_{\mathrm{C}}=50 \%$ and $\left[\mathrm{H}_{2} \mathrm{O}_{2}\right]_{\mathrm{W}}=10 \mathrm{ppm}$, it comes:

$\left[\mathrm{H}_{2} \mathrm{O}_{2}\right]_{\mathrm{S}}=5.5 \times 10^{-8} \mathrm{~mol} \mathrm{l}^{-1}$

This value was selected for this study. In contrast, the coefficient of 

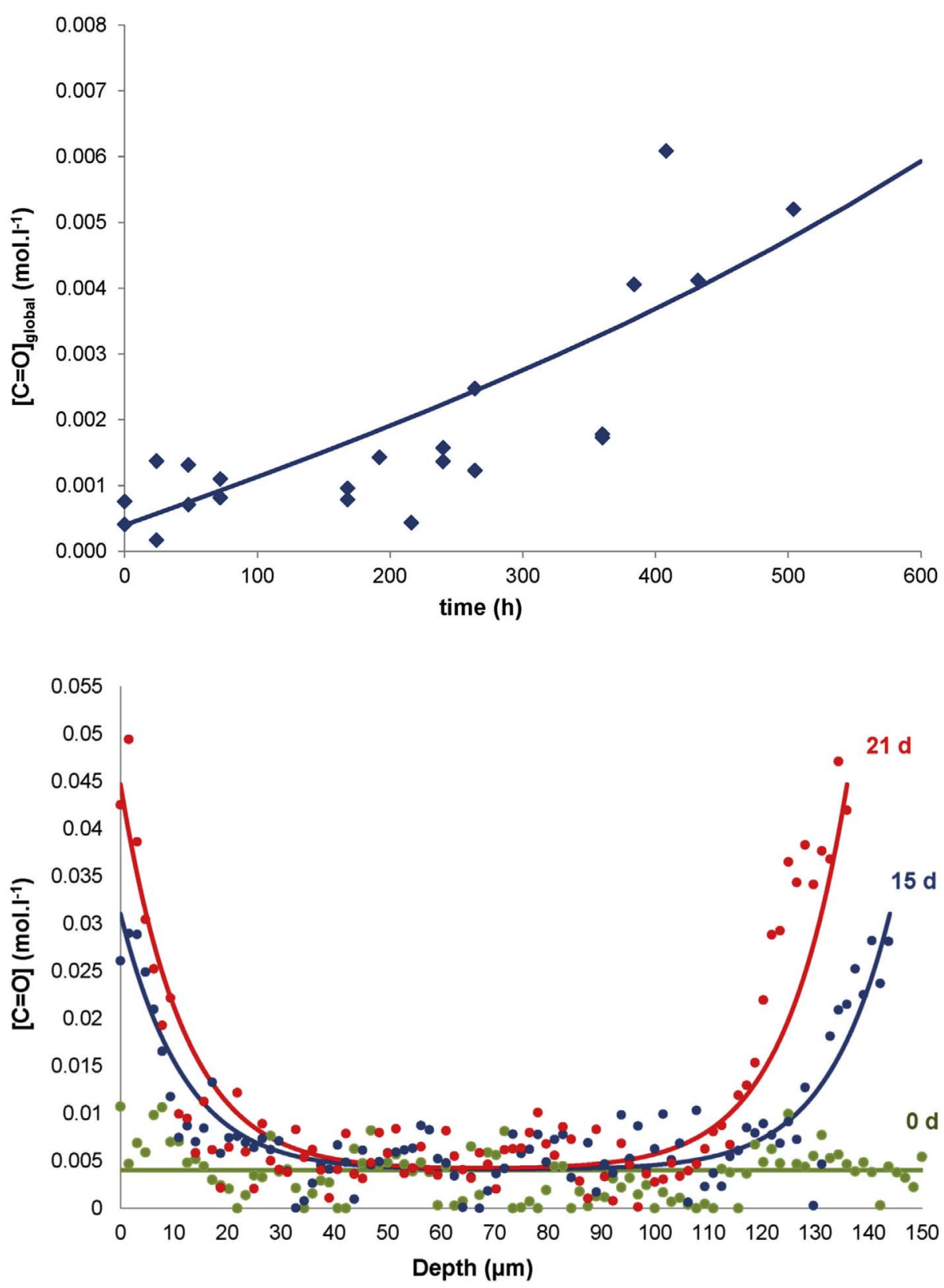

Fig. 9. Kinetic curve of average carbonyl concentration during the immersion of additive free $\mathrm{PE}$ films in a hydrogen peroxide solution regulated at $\left[\mathrm{H}_{2} \mathrm{O}_{2}\right]_{\mathrm{W}}=10 \mathrm{ppm}$ and $\mathrm{T}=60{ }^{\circ} \mathrm{C}$. Comparison between experimental data (symbols) and kinetic modeling (solid lines).
Fig. 10. Development of oxidation profiles in additive free $\mathrm{PE}$ films during their immersion (in days) in a hydrogen peroxide solution regulated at $\left[\mathrm{H}_{2} \mathrm{O}_{2}\right]_{\mathrm{W}}=10 \mathrm{ppm}$ and $\mathrm{T}=60{ }^{\circ} \mathrm{C}$. Comparison between experimental data (symbols) and kinetic modeling (solid lines).
Table 2

Values at $60{ }^{\circ} \mathrm{C}$ of the additional parameters used for modeling the PE oxidation in hydrogen peroxide solutions.

\begin{tabular}{lll}
\hline Kinetic parameter & Value at $60{ }^{\circ} \mathrm{C}$ & Unity \\
\hline $\mathrm{k}_{\mathrm{0h}}$ & $8.0 \times 10^{-1}$ & $\mathrm{~s}$ \\
$\mathrm{k}_{1 \mathrm{~h}}$ & $10^{9}$ & $\mathrm{~L} \cdot \mathrm{mol}^{-1} \cdot \mathrm{s}^{-1}$ \\
$\mathrm{k}_{7 \mathrm{k}}$ & $10^{10}$ & $\mathrm{~L} \cdot \mathrm{mol}^{-1} \cdot \mathrm{s}^{-1}$ \\
$\mathrm{D}_{\mathrm{H} 2 \mathrm{O} 2}$ & $8.0 \times 10^{-11}$ & $\mathrm{~m}^{2} \cdot \mathrm{s}^{-1}$ \\
$\mathrm{D}_{\mathrm{HO}}$ & $3.7 \times 10^{-10}$ & $\mathrm{~m}^{2} \cdot \mathrm{s}^{-1}$ \\
\hline
\end{tabular}

$\mathrm{H}_{2} \mathrm{O}_{2}$ diffusion $\left(\mathrm{D}_{\mathrm{H} 2 \mathrm{O} 2}\right)$ and the rate constants of $\mathrm{H}_{2} \mathrm{O}_{2}$ decomposition $\left(\mathrm{k}_{\mathrm{Oh}}\right)$ and addition of $\mathrm{HO}^{*}$ radicals onto $\mathrm{P}^{*}$ radicals $\left(\mathrm{k}_{7 \mathrm{~h}}\right)$ were determined by using the kinetic model as an inverse resolution method. As an example, the simulations of the kinetic curve of average carbonyl concentration and the development of oxidation profiles in PE films, during their immersion in a hydrogen peroxide solution regulated at $\left[\mathrm{H}_{2} \mathrm{O}_{2}\right]_{\mathrm{W}}=10 \mathrm{ppm}$ and $\mathrm{T}=60^{\circ} \mathrm{C}$, are reported in Figs. 9 and 10. It can be noticed a satisfying agreement between theory and experiments. The values of all the parameters used for these simulations are given in Tables 1 and 2.

c) Finally, the last 7 unknown parameters, i.e. the coefficients of $\mathrm{ClOH}, \mathrm{Cl}_{2}$ and $\mathrm{Cl} \cdot$ diffusion $\left(\mathrm{D}_{\mathrm{ClOH}}, \mathrm{D}_{\mathrm{Cl} 2}, \mathrm{D}_{\mathrm{Cl}} \cdot\right)$ and the rate constants of $\mathrm{ClOH}$ and $\mathrm{Cl}_{2}$ decomposition $\left(\mathrm{k}_{0 \mathrm{a}}, \mathrm{k}_{0 \mathrm{c}}\right.$ ), polymer attack by $\mathrm{Cl} \cdot$ radicals $\left(\mathrm{k}_{1 \mathrm{c}}\right)$ and addition of $\mathrm{Cl}$ - radicals onto $\mathrm{P}$ - radicals $\left(\mathrm{k}_{7 \mathrm{c}}\right)$, were determined by adjusting as closely as possible the experimental results

Table 3

Values at $60{ }^{\circ} \mathrm{C}$ of the additional parameters used for modeling the PE oxidation in bleach solutions.

\begin{tabular}{lll}
\hline Kinetic parameter & Value at $60{ }^{\circ} \mathrm{C}$ & Unity \\
\hline $\mathrm{k}_{0 \mathrm{a}}$ & 1.8 & $\mathrm{~s}^{-1}$ \\
$\mathrm{k}_{0 \mathrm{c}}$ & $3.0 \times 10^{-5}$ & $\mathrm{~s}$ \\
$\mathrm{k}_{1 \mathrm{c}}$ & $1.5 \times 10^{-3}$ & $\mathrm{~L} \cdot \mathrm{mol}^{-1} \cdot \mathrm{s}^{-1}$ \\
$\mathrm{k}_{7 \mathrm{c}}$ & $3.0 \times 10^{9}$ & $\mathrm{~L} \cdot \mathrm{mol}^{-1} \cdot \mathrm{s}^{-1}$ \\
$\mathrm{D}_{\mathrm{ClOH}}$ & $10^{-10}$ & $\mathrm{~m}^{2} \cdot \mathrm{s}^{-1}$ \\
$\mathrm{D}_{\mathrm{Cl} 2}$ & $10^{-14}$ & $\mathrm{~m}^{2} \cdot \mathrm{s}^{-1}$ \\
$\mathrm{D}_{\mathrm{Cl}}$ & $8.0 \times 10^{-12}$ & $\mathrm{~m}^{2} \cdot \mathrm{s}^{-1}$ \\
\hline
\end{tabular}


obtained for PE films immersed in bleach solutions (Figs. 6a, 7 and 8). It can be noticed a satisfying agreement between theory and experiments. The values of all the parameters used for these simulations are given in Tables 1-3. They call for the following comments:

- $\mathrm{ClOH}$ is much more unstable than $\mathrm{Cl}_{2}$ within the $\mathrm{PE}$ matrix. It is thus the main source of radicals. It is firstly responsible for the polymer degradation in bleach solutions according to scenario S3.

- As expected, $\mathrm{HO}$ - radicals are much more reactive than $\mathrm{Cl}$ - radicals:

$\frac{\mathrm{k}_{1 \mathrm{~h}}}{\mathrm{k}_{1 \mathrm{c}}} \approx 10^{12} \mathrm{at} 60^{\circ} \mathrm{C}$

This large difference in reactivity is difficult to perceive through the rate constants $\left(\mathrm{k}_{7 \mathrm{~h}}\right.$ and $\mathrm{k}_{7 \mathrm{C}}$ ) of addition of these radicals onto $\mathrm{P} \cdot$ radicals due to the high mobility (by valence migration) of $\mathrm{P}$. radicals within the PE matrix: $\mathrm{P} \cdot+\mathrm{PH} \rightarrow \mathrm{PH}+\mathrm{P} \cdot$.

In addition, it can be pointed out that the values of $k_{1 C}$ and $k_{7 C}$ are very close to those reported for $\mathrm{ClO}_{2}$ in a previous publication [12]. Thus, these two chlorinated radicals would have almost the same reactivity.

- The diffusion coefficients of the molecular reagents ranks in the right order when considering their molecular size:

$\mathrm{Cl}_{2} \ll \mathrm{Cl}^{-}<\mathrm{O}_{2}$

but also their polarity:

$\mathrm{H}_{2} \mathrm{O}_{2}<\mathrm{ClOH}<\mathrm{HO}^{*}$

- It is thus confirmed that $\mathrm{Cl}$ - radicals migrate more deeply than $\mathrm{HO}$ radicals into the PE sample thickness, thus contributing, in addition to scenario S3, to the large value of the superficial oxidized layer. In a first approach, their depth of penetration can be estimated from Equation (7):

$\mathrm{L}_{\mathrm{Cl}} \approx\left(\frac{\mathrm{D}_{\mathrm{Cl}}}{\mathrm{K}_{\mathrm{Cl}}}\right)^{\frac{1}{2}} \approx\left(\frac{\mathrm{D}_{\mathrm{Cl}}}{\mathrm{k}_{\mathrm{lc}}[\mathrm{PH}]}\right)^{\frac{1}{2}}$

It comes:

$\mathrm{L}_{\mathrm{Cl}} \cdot \approx 10 \mu \mathrm{m}$

In contrast, the application of Equation (7) to $\mathrm{HO}^{\circ}$ radicals leads to $\mathrm{L}_{\mathrm{HO}}$. values lower than $1 \mathrm{~nm}$. Thus, these radicals are scavenged as soon as they are formed within the PE matrix.

Once validated at the molecular level, the kinetic model was used to predict the consequences of oxidation at the macromolecular scale. The classical Saito's equation $[62,63]$ was used for simulating the changes in weight average molar mass of PE films reported in Fig. 6b:
$\frac{1}{\mathrm{M}_{\mathrm{W}}}-\frac{1}{\mathrm{M}_{\mathrm{W} 0}}=\frac{\mathrm{S}}{2}-2 \mathrm{X}$

$\mathrm{M}_{\mathrm{W}}=\frac{2 \mathrm{M}_{\mathrm{W} 0}}{2+(\mathrm{S}-4 \mathrm{X}) \mathrm{M}_{\mathrm{W} 0}}$

Here again, it can be noticed a satisfying agreement between theory and experiments. The kinetic model perfectly accounts, without making additional assumption and without adding additional parameter, that, after a few weeks, oxidation leads to a catastrophic decrease in the average molar mass due to the large predominance of chain scissions over crosslinking. It was concluded that crosslinking results only from the coupling of $\mathrm{PO}_{2}{ }^{\circ}$ and $\mathrm{P}^{*}$ radicals, while chain scissions result only from the rearrangement by $\beta$ scission of alkoxy (PO') radicals.

\section{Conclusion}

The chemical interactions between additive free PE and bleach have been investigated in solutions maintained at a temperature of $60{ }^{\circ} \mathrm{C}$, a free chlorine concentration of $100 \mathrm{ppm}$, and a $\mathrm{pH}=4,5$ or 7. A scenario was proposed for tentatively explaining why oxidation reaches its maximum rate at $\mathrm{pH}=5$ and occurs in a relatively large superficial thickness (about 50-100 $\mu \mathrm{m}$ thick), almost independent of the $\mathrm{pH}$ value, despite the high reactivity of the involved radicals (in particular $\mathrm{HO}^{\circ}$ ). According to this scenario, $\mathrm{ClOH}$ and $\mathrm{Cl}_{2}$ would migrate deeply into the PE matrix prior to dissociate into radicals and then, initiate a radical chain oxidation.

A kinetic model has been derived from this scenario. Many of its parameters were determined in previous studies dedicated to simpler cases of oxidative ageing. The remaining 12 unknown parameters have been determined from structure/transport property and structure/reactivity relationships reported in the literature, but also from complementary ageing experiments of immersion in hydrogen peroxide solutions. This kinetic model predicts accurately all the experimental data collected in this study. It gives access to the orders of magnitude of the transport properties of chlorinated disinfectants $\left(\mathrm{Cl}_{2}\right.$ and $\left.\mathrm{ClOH}\right)$ and their radical species $\left(\mathrm{Cl}^{\circ}\right.$ and $\left.\mathrm{HO}^{\circ}\right)$, but also to the orders of magnitude of the rate constants of the elementary reactions in which they are involved. It was found that $\mathrm{Cl}^{\circ}$ radicals are much less reactive than $\mathrm{HO}^{\circ}$ radicals, but are of the same reactivity as $\mathrm{ClO}_{2}$. The values of these parameters will have to be refined in future studies.

The next challenges will consist in introducing the stabilizing effects of commercial blends of antioxidants into the kinetic model for tentatively predicting the degradation states (in particular, the profiles of antioxidant consumption and oxidation products) in the inner wall of industrial PE pipes in service.

\section{Appendix A. Kinetic model for predicting PE oxidation in a bleach solution}

The mechanistic scheme describing the radical chain oxidation of additive free PE in a bleach solution can be summarized as follows. It is composed of five main stages:

Decomposition:

(0a) $\mathrm{ClOH} \rightarrow \mathrm{Cl} \cdot+\cdot \mathrm{OH}$

(0c) $\mathrm{Cl}_{2} \rightarrow 2 \mathrm{Cl}$.

Initiation:

(Iu) $\mathrm{POOH} \rightarrow 2 \mathrm{P} \cdot+\gamma_{\mathrm{CO}} \mathrm{P}=\mathrm{O}+\left(1-\gamma_{\mathrm{CO}}\right) \mathrm{P}-\mathrm{OH}+\gamma_{\mathrm{S}} \mathrm{S}$

$\left(\mathrm{k}_{1 \mathrm{u}}\right)$

(Ib) $2 \mathrm{POOH} \rightarrow \mathrm{P} \cdot+\mathrm{PO}_{2} \cdot+\gamma_{\mathrm{CO}} \mathrm{P}=\mathrm{O}+\left(1-\gamma_{\mathrm{CO}}\right) \mathrm{P}-\mathrm{OH}+\gamma_{\mathrm{S}} \mathrm{S}$

$\left(\mathrm{k}_{1 \mathrm{~b}}\right)$

(Ic) $\mathrm{Cl} \cdot+\mathrm{PH} \rightarrow \mathrm{HCl}+\mathrm{P}$.

(Ih) $\mathrm{HO} \cdot+\mathrm{PH} \rightarrow \mathrm{H}_{2} \mathrm{O}+\mathrm{P}$.

$\left(\mathrm{k}_{1 \mathrm{c}}\right)$

Propagation:

$\left(\mathrm{k}_{1 \mathrm{~h}}\right)$

(II) $\mathrm{P} \cdot+\mathrm{O}_{2} \rightarrow \mathrm{PO}_{2}$.

(III) $\mathrm{PO}_{2} \cdot+\mathrm{PH} \rightarrow \mathrm{POOH}+\mathrm{P}$.

Bimolecular recombination: 
(IV) $\mathrm{P} \cdot+\mathrm{P} \cdot \rightarrow \gamma_{4} \mathrm{P}-\mathrm{P}+\left(1-\gamma_{4}\right) \mathrm{PH}+\left(1-\gamma_{4}\right) \mathrm{F}+\gamma_{4} \mathrm{X}$

(V) $\mathrm{P} \cdot+\mathrm{PO}_{2} \cdot \rightarrow \gamma_{5} \mathrm{POOP}+\left(1-\gamma_{5}\right) \mathrm{PH}+\left(1-\gamma_{5}\right) \mathrm{POOH}+\gamma_{5} \mathrm{X}$

(VIa) $\mathrm{PO}_{2} \cdot+\mathrm{PO}_{2} \cdot \rightarrow[\mathrm{PO} \cdot \cdot \mathrm{OP}]_{\text {cage }}+\mathrm{O}_{2}$

(VIb) $[\mathrm{PO} \cdot \cdot \mathrm{OP}]_{\text {cage }} \rightarrow \mathrm{POOP}+\mathrm{X}$

(VIc) $[\mathrm{PO} \cdot \cdot \mathrm{OP}]_{\text {cage }} \rightarrow \mathrm{P}=\mathrm{O}+\mathrm{P}-\mathrm{OH}$

(VId) $[\mathrm{PO} \cdot \cdot \mathrm{OP}]_{\text {cage }} \rightarrow 2 \mathrm{P} \cdot+2 \gamma_{\mathrm{CO}} \mathrm{P}=\mathrm{O}+2\left(1-\gamma_{\mathrm{CO}}\right) \mathrm{P}-\mathrm{OH}+2 \gamma_{\mathrm{S}} \mathrm{S}$

in which:

a) $\mathrm{ClOH}$ and $\mathrm{Cl}_{2}$ account respectively for hypochlorous acid and chlorine having penetrated into the PE matrix

b) $\mathrm{PH}$ accounts for secondary $\mathrm{C}-\mathrm{H}$ bonds (i.e. methylene groups)

c) $\mathrm{Cl} \cdot \mathrm{HO} \cdot \mathrm{P} \cdot, \mathrm{PO}_{2} \cdot$ and $\mathrm{PO} \cdot$ account respectively for chlorine, hydroxyl, alkyl, peroxy and alkoxy radicals;

d) $\mathrm{POOH}$, $\mathrm{POOP}, \mathrm{P}=\mathrm{O}$ and $\mathrm{P}-\mathrm{OH}$ account respectively for hydroperoxides, dialkyl peroxides, carbonyls and alcohols as macromolecular oxidation products;

e) $\mathrm{P}-\mathrm{Cl}$ is an attempt at representing the grafting of chlorine onto the polymer chain as organic chlorides

f) F, $\mathrm{S}$ and $\mathrm{X}$ account for double bonds, chain scissions and crosslinking nodes (i.e. covalent bridges) respectively;

g) $\gamma_{s}$ is the yield of $\beta$-scission of PO - radicals (leading to aldehydes) in competition with hydrogen abstraction (leading to alcohols), irrespectively of the molecularity of the initiation reaction;

h) From a practical point of view, it is more convenient to use an apparent yield $\gamma_{\mathrm{co}}$ for the carbonyl production owing to the high uncertainty on the nature of these species and the value of their corresponding molar extinction coefficients [40];

i) $\gamma_{4}$ and $\gamma_{5}$ are the respective yields for the coupling of alkyl-alkyl and alkyl-peroxy radicals in competition with disproportionation

j) $\mathrm{k}_{\mathrm{i}}$ are the elementary rate constants of the different chemical reactions under consideration.

Thus, two main types of initiation reaction are in competition: the decomposition of hydroperoxides (POOH) according to an unimolecular (Iu) or bimolecular mode (Ib), and the direct polymer attack by radical species $(\mathrm{Cl} \cdot$ and $\mathrm{HO} \cdot)$ formed by dissociation of chlorinated species $\left(\mathrm{ClOH}\right.$ and $\left.\mathrm{Cl}_{2}\right)$ having beforehand migrated into the PE matrix. The former type of initiation is strongly thermo-activated: the activation energy of the corresponding rate constant ranges typically between 140 (for $\mathrm{k}_{1 \mathrm{u}}$ ) and $105 \mathrm{~kJ} \mathrm{~mol}^{-1}$ (for $\mathrm{k}_{1 \mathrm{~b}}$ ) [47]. In contrast, because of the high reactivity of $\mathrm{HO} \cdot$ radicals [49], but presumably also of $\mathrm{Cl}$ - radicals, the two last initiations are almost independent of temperature. As a result, at low temperature close to ambient, the oxidation should be mainly initiated by chlorinated species.

A kinetic model was derived from this mechanistic scheme by applying the classical rules of the chemical kinetics. It is composed of 14 non-linear differential equations:

$\frac{\mathrm{d}[\mathrm{ClOH}]}{\mathrm{dt}}=-\mathrm{k}_{0 \mathrm{a}}[\mathrm{ClOH}]+\mathrm{D}_{\mathrm{ClOH}} \frac{\partial^{2}[\mathrm{ClOH}]}{\partial \mathrm{z}^{2}}$
$\frac{\mathrm{d}\left[\mathrm{Cl}_{2}\right]}{\mathrm{dt}}=-\mathrm{k}_{0 \mathrm{c}}\left[\mathrm{Cl}_{2}\right]+\mathrm{D}_{\mathrm{Cl}_{2}} \frac{\partial^{2}\left[\mathrm{Cl}_{2}\right]}{\partial \mathrm{z}^{2}}$
$\frac{\mathrm{d}\left[\mathrm{Cl}^{\cdot}\right]}{\mathrm{dt}}=\mathrm{k}_{0 \mathrm{a}}[\mathrm{ClOH}]+2 \mathrm{k}_{0 \mathrm{c}}\left[\mathrm{Cl}_{2}\right]-\mathrm{k}_{1 \mathrm{c}}\left[\mathrm{Cl} \cdot[\mathrm{PH}]-\mathrm{k}_{7 \mathrm{c}}[\mathrm{Cl} \cdot]\left[\mathrm{P}^{\cdot}\right]+\mathrm{D}_{\mathrm{Cl}^{*}} \frac{\partial^{2}\left[\mathrm{Cl}^{\cdot}\right]}{\partial \mathrm{z}^{2}}\right.$
$\frac{\mathrm{d}[\mathrm{HO} \cdot]}{\mathrm{dt}}=\mathrm{k}_{0 \mathrm{a}}[\mathrm{ClOH}]-\mathrm{k}_{1 \mathrm{~h}}[\mathrm{HO} \cdot][\mathrm{PH}]-\mathrm{k}_{7 \mathrm{~h}}[\mathrm{HO} \cdot]\left[\mathrm{P}^{*}\right]+\mathrm{D}_{\mathrm{HO}} \cdot \frac{\partial^{2}\left[\mathrm{HO}^{*}\right]}{\partial \mathrm{z}^{2}}$
$\frac{\mathrm{d}[\mathrm{POOH}]}{\mathrm{dt}}=-\mathrm{k}_{1 \mathrm{u}}[\mathrm{POOH}]-2 \mathrm{k}_{1 \mathrm{~b}}[\mathrm{POOH}]^{2}+\mathrm{k}_{3}\left[\mathrm{PO}_{2}^{*}\right][\mathrm{PH}]+\left(1-\gamma_{5}\right) \mathrm{k}_{5}\left[\mathrm{P}^{\bullet}\right]\left[\mathrm{PO}_{2}^{*}\right]$

$\frac{\mathrm{d}\left[\mathrm{P}^{\bullet}\right]}{\mathrm{dt}}=2 \mathrm{k}_{1 \mathrm{u}} \mathrm{f}_{\mathrm{PH}}[\mathrm{POOH}]+\mathrm{k}_{1 \mathrm{~b}} \mathrm{f}_{\mathrm{PH}}[\mathrm{POOH}]^{2}+\mathrm{k}_{1 \mathrm{c}}\left[\mathrm{Cl}^{\cdot}\right][\mathrm{PH}]+\mathrm{k}_{1 \mathrm{~h}}\left[\mathrm{HO}^{\bullet}\right][\mathrm{PH}]$

$-\mathrm{k}_{2}\left[\mathrm{O}_{2}\right]\left[\mathrm{P}^{\cdot}\right]+\mathrm{k}_{3}\left[\mathrm{PO}_{2}^{*}\right][\mathrm{PH}]-2 \mathrm{k}_{4}\left[\mathrm{P}^{\cdot}\right]^{2}-\mathrm{k}_{5} \mathrm{f}_{\mathrm{PH}}\left[\mathrm{P}^{\cdot}\right]\left[\mathrm{PO}_{2}^{*}\right]$

$+2 \mathrm{k}_{6 \mathrm{~d}} \mathrm{f}_{\mathrm{PH}}[\mathrm{PO} \cdot \cdot \mathrm{OP}]_{\text {cage }}-\mathrm{k}_{7 \mathrm{c}}\left[\mathrm{Cl}^{\cdot}\right]\left[\mathrm{P}^{*}\right]-\mathrm{k}_{7 \mathrm{~h}}\left[\mathrm{HO}^{*}\right]\left[\mathrm{P}^{*}\right]$

$\frac{\mathrm{d}\left[\mathrm{PO}_{2}^{*}\right]}{\mathrm{dt}}=\mathrm{k}_{1 \mathrm{~b}} \mathrm{f}_{\mathrm{PH}}[\mathrm{POOH}]^{2}+\mathrm{k}_{2}\left[\mathrm{O}_{2}\right]\left[\mathrm{P}^{*}\right]-\mathrm{k}_{3}\left[\mathrm{PO}_{2}^{*}\right][\mathrm{PH}]-\mathrm{k}_{5} \mathrm{f}_{\mathrm{PH}}\left[\mathrm{P}^{\bullet}\right]\left[\mathrm{PO}_{2}^{*}\right]$

$-2 \mathrm{k}_{6 \mathrm{a}}\left[\mathrm{PO}_{2}^{*}\right]^{2}$

$\frac{\mathrm{d}[\mathrm{PO} \cdot \mathrm{OP}]_{\text {cage }}}{\mathrm{dt}}=\mathrm{k}_{6 \mathrm{a}}\left[\mathrm{PO}_{2}^{*}\right]^{2}-\left(\mathrm{k}_{6 \mathrm{~b}}+\mathrm{k}_{6 \mathrm{c}}+\mathrm{k}_{6 \mathrm{~d}} \mathrm{f}_{\mathrm{PH}}\right)[\mathrm{PO} \cdot \mathrm{OP}]_{\text {cage }}$

$\frac{\mathrm{d}[\mathrm{PH}]}{\mathrm{dt}}=-\left(2+\gamma_{\mathrm{S}}\right) \mathrm{k}_{1 \mathrm{u}} \mathrm{f}_{\mathrm{PH}}[\mathrm{POOH}]-\left(1+\gamma_{\mathrm{S}}\right) \mathrm{k}_{1 \mathrm{~b}} \mathrm{f}_{\mathrm{PH}}[\mathrm{POOH}]^{2}-\mathrm{k}_{1 \mathrm{c}}[\mathrm{Cl} \cdot][\mathrm{PH}]$

$-\mathrm{k}_{1 \mathrm{~h}}[\mathrm{HO} \cdot][\mathrm{PH}]-\mathrm{k}_{3}\left[\mathrm{PO}_{2}^{*}\right][\mathrm{PH}]-\left(1-\gamma_{5}\right) \mathrm{k}_{5} \mathrm{f}_{\mathrm{PH}}\left[\mathrm{P}^{\bullet}\right]\left[\mathrm{PO}_{2}^{*}\right]$

$-2\left(1+\gamma_{\mathrm{S}}\right) \mathrm{k}_{6 \mathrm{~d}} \mathrm{f}_{\mathrm{PH}}\left[\mathrm{PO} \cdot{ }^{\cdot} \mathrm{OP}\right]_{\text {cage }}-\mathrm{k}_{7 \mathrm{c}}\left[\mathrm{Cl}^{\cdot}\right]\left[\mathrm{P}^{*}\right]-\mathrm{k}_{7 \mathrm{~h}}\left[\mathrm{HO}^{*}\right]\left[\mathrm{P}^{*}\right]$ 
$\frac{\mathrm{d}\left[\mathrm{O}_{2}\right]}{\mathrm{dt}}=-\mathrm{k}_{2}\left[\mathrm{O}_{2}\right]\left[\mathrm{P}^{\bullet}\right]+\mathrm{k}_{6 \mathrm{a}}\left[\mathrm{PO}_{2}^{*}\right]^{2}+\mathrm{D}_{\mathrm{O}_{2}} \frac{\partial^{2}\left[\mathrm{O}_{2}\right]}{\partial \mathrm{z}^{2}}$

$\frac{\mathrm{d}[\mathrm{P}=\mathrm{O}]}{\mathrm{dt}}=\gamma_{\mathrm{CO}} \mathrm{k}_{1 \mathrm{u}} \mathrm{f}_{\mathrm{PH}}[\mathrm{POOH}]+\gamma_{\mathrm{CO}} \mathrm{k}_{1 \mathrm{~b}} \mathrm{f}_{\mathrm{PH}}[\mathrm{POOH}]^{2}+\mathrm{k}_{6 \mathrm{c}}[\mathrm{PO} \cdot \mathrm{OP}]_{\text {cage }}$

$+2 \gamma_{\mathrm{CO}} \mathrm{k}_{6 \mathrm{~d}} \mathrm{f}_{\mathrm{PH}}[\mathrm{PO} \cdot \cdot \mathrm{OP}]_{\text {cage }}$

$\frac{\mathrm{d}[\mathrm{P}-\mathrm{Cl}]}{\mathrm{dt}}=\mathrm{k}_{7 \mathrm{c}}\left[\mathrm{Cl}^{\cdot}\right]\left[\mathrm{P}^{\cdot}\right]$

$\frac{\mathrm{dS}}{\mathrm{dt}}=\gamma_{\mathrm{S}} \mathrm{k}_{1 \mathrm{u}} \mathrm{f}_{\mathrm{PH}}[\mathrm{POOH}]+\gamma_{\mathrm{S}} \mathrm{k}_{1 \mathrm{~b}} \mathrm{f}_{\mathrm{PH}}[\mathrm{POOH}]^{2}+2 \gamma_{\mathrm{S}} \mathrm{k}_{6 \mathrm{~d}} \mathrm{f}_{\mathrm{PH}}[\mathrm{PO} \cdot \mathrm{OP}]_{\text {cage }}$

$\frac{\mathrm{dX}}{\mathrm{dt}}=\gamma_{4} \mathrm{k}_{4}\left[\mathrm{P}^{\bullet}\right]^{2}+\gamma_{5} \mathrm{k}_{5} \mathrm{f}_{\mathrm{PH}}\left[\mathrm{P}^{\bullet}\right]\left[\mathrm{PO}_{2}^{*}\right]+\mathrm{k}_{6 \mathrm{~b}}[\mathrm{PO} \cdot \mathrm{OP}]_{\text {cage }}$

where $\mathrm{z}$ is the depth beneath the sample surface and $\mathrm{D}_{\mathrm{ClOH}}, \mathrm{D}_{\mathrm{Cl} 2}, \mathrm{D}_{\mathrm{Cl}} \cdot \mathrm{D}_{\mathrm{HO}} \cdot$ and $\mathrm{D}_{\mathrm{O} 2}$ are the respective diffusion coefficients of $\mathrm{ClOH}, \mathrm{Cl}{ }_{2}, \mathrm{Cl} \cdot \mathrm{HO}$. and $\mathrm{O}_{2}$ in the sample thickness.

$\mathrm{f}_{\mathrm{PH}}$ is a mathematical function introduced in the system of differential equations for avoiding that the substrate concentration becomes negative at high conversion ratios of oxidation process. In a first approach, a hyperbolic form has been chosen to describe the changes of $\mathrm{f}_{\mathrm{PH}}$ versus $[\mathrm{PH}]$ :

$\mathrm{f}_{\mathrm{PH}}=\frac{[\mathrm{PH}]}{[\mathrm{PH}]+\varepsilon}$

with typically $\varepsilon=10^{-2} \ll 1$. This function does not induce significant changes of the oxidation kinetics below a conversion value of about $99 \%$. The boundary conditions are:

a) When $\mathrm{t}=0,[\mathrm{ClOH}]=[\mathrm{ClOH}]_{\mathrm{S}}$ and $\left[\mathrm{Cl}_{2}\right]=\left[\mathrm{Cl}_{2}\right]_{\mathrm{S}}$ (equilibrium concentrations of chlorinated species) at $\mathrm{z}=0$ and $\mathrm{z}=\mathrm{L}$ (i.e. at the sample surfaces, $\mathrm{L}$ being the sample thickness) and $[\mathrm{ClOH}]=\left[\mathrm{Cl}_{2}\right]=0$ everywhere else.

b) When $\mathrm{t}=0,[\mathrm{Cl} \cdot]=[\mathrm{HO} \cdot]=[\mathrm{P} \cdot]=\left[\mathrm{PO}_{2} \cdot\right]=[\mathrm{PO} \cdot \cdot \mathrm{OP}]_{\text {cage }}=[\mathrm{P}=\mathrm{O}]=[\mathrm{P}-\mathrm{Cl}]=\mathrm{S}=\mathrm{X}=0,[\mathrm{POOH}]=[\mathrm{POOH}]_{0}=10^{-2} \mathrm{~mol} 1^{-1}$, $[\mathrm{PH}]=[\mathrm{PH}]_{0}=60 \mathrm{~mol} \mathrm{l}^{-1}$ (initial concentration in methylene groups), and $\left[\mathrm{O}_{2}\right]=\left[\mathrm{O}_{2}\right]_{\mathrm{S}}=3.810^{-4}$ mol $1^{-1}$ (equilibrium concentration of oxygen) at every $\mathrm{z}$.

c) When $\mathrm{t}>0,\left[\mathrm{O}_{2}\right]=\left[\mathrm{O}_{2}\right]_{\mathrm{S}}=3.810^{-4} \mathrm{~mol} \mathrm{l}^{-1},[\mathrm{ClOH}]=[\mathrm{ClOH}]_{\mathrm{S}}$ and $\left[\mathrm{Cl}_{2}\right]=\left[\mathrm{Cl}_{2}\right]_{\mathrm{S}}$ at $\mathrm{z}=0$ and $\mathrm{z}=\mathrm{L}$.

The numerical method for solving such a system of differential equations has been already described in a previous publication [50]. Very briefly, it is based on implicit or semi-implicit algorithms recommended for solving stiff problems of chemical kinetics. Indeed, these algorithms give a satisfying approximate solution for a reasonable cost of calculation. The results reported in this study were obtained by applying the ODE23s solver of Matlab commercial software based on the semi-implicit Rosenbrock's algorithm [51].

Eqs A-1 to A-14 were integrated numerically for accessing the concentration profiles (in the sample thickness, along the $\mathrm{z}$ abscissa) of all the chemical species, and their changes against exposure time. The corresponding average concentrations were deduced by integrating these profiles over the entire sample thickness with the trapezoid method.

\section{Appendix B. Equilibrium concentration of $\mathrm{ClO}_{2}$ and $\mathrm{Cl}_{2}$}

The transport properties of chlorinated species into PE have never been studied to our knowledge. But, they would be close to those of much better known vapors or gases which can be thus used for estimating some key characteristics of chlorinated species, in particular their Lennard-Jones temperature $\mathrm{T}_{\mathrm{LJ}}$ :

$\mathrm{T}_{\mathrm{LJ}}=\frac{\varepsilon}{\mathrm{k}}$

where $\varepsilon$ is the pre-factor of the Lennard-Jones potential and $\mathrm{k}$ the Boltzmann constant.

Table B1

Molar mass (M), boiling point $\left(T_{b}\right)$, critical temperature ( $T_{c r}$ ), vaporization enthalpy $\left(\Delta \mathrm{H}_{\mathrm{V}}\right)$, ratio $\Delta \mathrm{H}_{\mathrm{V}} / \mathrm{R} \mathrm{T}_{\mathrm{b}}$ and Lennard-Jones temperature $\left(\mathrm{T}_{\mathrm{LJ}}\right)$. All the characteristics, except $\mathrm{T}_{\mathrm{LJ}}$ of $\mathrm{ClO}_{2}$ and $\mathrm{Cl}_{2}$, were taken from Handbooks, for instance from Ref. [24].

\begin{tabular}{lllllr}
\hline Molecule & $\begin{array}{l}\mathrm{M} \\
\left(\mathrm{g} \cdot \mathrm{mol}^{-1}\right)\end{array}$ & $\begin{array}{l}\mathrm{T}_{\mathrm{b}} \\
(\mathrm{K})\end{array}$ & $\begin{array}{l}\mathrm{T}_{\mathrm{cr}} \\
(\mathrm{K})\end{array}$ & $\begin{array}{l}\Delta \mathrm{H}_{\mathrm{V}} \\
\left(\mathrm{kJ} \cdot \mathrm{mol}^{-1}\right)\end{array}$ & $\begin{array}{l}\Delta \mathrm{H}_{\mathrm{V}} / \mathrm{RT}_{\mathrm{b}} \\
(\mathrm{K})\end{array}$ \\
\hline $\mathrm{SO}_{2}$ & 64 & 263 & 431 & 24.8 & 31.3 \\
$\mathrm{ClO}_{2}$ & 67.5 & 284 & 426 & 27.3 & 11.5 \\
$\mathrm{Cl}_{2}$ & 71 & 239 & 417 & 20.4 & 10.3 \\
$\mathrm{C}_{5} \mathrm{H}_{12}$ & 72.1 & 309 & 470 & 26.4 & 369 \\
\hline
\end{tabular}

In Table B-1, it can be seen that $\mathrm{SO}_{2}$ and $\mathrm{C}_{5} \mathrm{H}_{12}$ exhibit close molecular size (assimilated to molar mass $\mathrm{M}$ ) and cohesive properties (represented by the ratio $\Delta \mathrm{H}_{\mathrm{V}} / \mathrm{R} \mathrm{T}_{\mathrm{b}}$ ) than $\mathrm{ClO}_{2}$ and $\mathrm{Cl}_{2}$ respectively. Since their $\mathrm{T}_{\mathrm{LJ}}$ is known, it can be assumed that:

$\mathrm{T}_{\mathrm{LJ}}(\mathrm{X})=\mathrm{T}_{\mathrm{LJ}}(\mathrm{Y}) \frac{\Delta \mathrm{H}_{\mathrm{V}}(\mathrm{X})}{\Delta \mathrm{H}_{\mathrm{V}}(\mathrm{Y})}$ 
where $\mathrm{X}$ and $\mathrm{Y}$ designate a couple of molecules, and $\Delta \mathrm{H}_{\mathrm{V}}$ is their vaporization enthalpy.

The numerical application of Equ. B-2 gives:

$\mathrm{T}_{\mathrm{LJ}}=369 \mathrm{~K}$ for $\mathrm{ClO}_{2}$

$\mathrm{T}_{\mathrm{LJ}}=353 \mathrm{~K}$ for $\mathrm{Cl}_{2}$

The solubility of chlorinated species in PE at $298 \mathrm{~K}$ can be calculated from an empirical equation first established by Van Amerongen [52] for little polar elastomers, then used by Michaels and Bixler [53,54] for the amorphous phase of PE:

$\log \mathrm{S}_{\mathrm{a}}(298 \mathrm{~K})=-7,0+0,010 \mathrm{~T}_{\mathrm{LJ}}$

where $S_{a}$ is expressed in $\mathrm{cm}^{3} S T P . \mathrm{cm}^{-3} \cdot \mathrm{Pa}^{-1}$.

The numerical application of Equ. B-3 gives:

$\mathrm{S}_{\mathrm{a}}(298 \mathrm{~K})=4.9 \times 10^{-4} \mathrm{~cm}^{3}$ STP.cm ${ }^{-3} \cdot \mathrm{Pa}^{-1}$ i.e. $\mathrm{S}_{\mathrm{a}}(298 \mathrm{~K})=2.2 \times 10^{-5} \mathrm{~mol} \mathrm{~L}^{-1} \mathrm{~Pa}^{-1}$ for $\mathrm{ClO}_{2}$

$\mathrm{S}_{\mathrm{a}}(298 \mathrm{~K})=3.4 \times 10^{-4} \mathrm{~cm}^{3} \mathrm{STP} . \mathrm{cm}^{-3} \cdot \mathrm{Pa}^{-1}$ i.e. $\mathrm{S}_{\mathrm{a}}(298 \mathrm{~K})=1.5 \times 10^{-5} \mathrm{~mol} \mathrm{~L}^{-1} \mathrm{~Pa}^{-1}$ for $\mathrm{Cl}_{2}$

For a PE sample of crystallinity ratio $\mathrm{X}_{\mathrm{C}}$, one can write:

$\mathrm{S}=\mathrm{S}_{\mathrm{a}}\left(1-\mathrm{X}_{\mathrm{C}}\right)$

The same authors gave the expression for the heat of dissolution $\mathrm{H}_{\mathrm{S}}$ into the $\mathrm{PE}$ matrix:

$\frac{\mathrm{H}_{\mathrm{S}}}{\mathrm{R}}=\left(1000-10 \mathrm{~T}_{\mathrm{LJ}}\right) \pm 500 \mathrm{~K}$

The numerical application of Equ. B-5 gives:

$\frac{\mathrm{H}_{\mathrm{S}}}{\mathrm{R}}=-2690 \pm 500 \mathrm{~K}$ for $\mathrm{ClO}_{2}$

$\frac{\mathrm{H}_{\mathrm{S}}}{\mathrm{R}}=-2530 \pm 500 \mathrm{~K}$ for $\mathrm{Cl}_{2}$

Thus, the dissolution of chlorinated species into the PE matrix is an exothermic process. In other words, $S$ is a decreasing function of temperature:

$\mathrm{S}=\mathrm{S}_{0} \exp \left(-\frac{\mathrm{H}_{\mathrm{S}}}{\mathrm{RT}}\right)$

with $\mathrm{S}_{0}=2.6 \times 10^{-9}\left(1-\mathrm{X}_{\mathrm{C}}\right) \mathrm{mol} \cdot \mathrm{L}^{-1} \cdot \mathrm{Pa}^{-1}$ and $\mathrm{H}_{\mathrm{S}}=-22380 \mathrm{~J} \mathrm{~mol}^{-1}$ for $\mathrm{ClO}_{2}$ and $\mathrm{S}_{0}=3.1 \times 10^{-9}\left(1-\mathrm{X}_{\mathrm{C}}\right) \mathrm{mol}^{-1} \mathrm{~L}^{-1} \mathrm{~Pa}^{-1}$ and $\mathrm{H}_{\mathrm{S}}=-$ $21060 \mathrm{~J} \mathrm{~mol}^{-1}$ for $\mathrm{Cl}_{2}$

For determining the concentration of chlorinated species in PE, it remains to know the partial pressure of chlorinated species $\mathrm{p}$ in the atmosphere, in equilibrium with the water solution. According to the equilibrium diagrams of water/chlorinated species systems reported in French technical publications [55-58], it can be written:

$\mathrm{p}=\mathrm{p}_{0} \exp \left(-\frac{\mathrm{E}_{\mathrm{p}}}{\mathrm{RT}}\right)$

with $\mathrm{p}_{0}=6.8 \times 10^{4}\left[\mathrm{ClO}_{2}\right]_{\mathrm{W}} \mathrm{Pa}$ and $\mathrm{E}_{\mathrm{p}}=26830 \mathrm{~J} \mathrm{~mol}^{-1}$ for $\mathrm{ClO}_{2}$ and $\mathrm{p}_{0}=1.15 \times 10^{11}\left[\mathrm{Cl}_{2}\right]_{\mathrm{W}} \mathrm{Pa}$ and $\mathrm{E}_{\mathrm{p}}=40190 \mathrm{~J} \mathrm{~mol}^{-1}$ for Cl$_{2}$ where $\left[\mathrm{ClO}_{2}\right]_{\mathrm{W}}$ and $\left[\mathrm{Cl}_{2}\right]_{\mathrm{W}}$ are the corresponding mass fractions of the chlorinated species in water, expressed in ppm. Let us remember that $\left[\mathrm{Cl}_{2}\right]_{\mathrm{W}}$ is given by Eq. $(11)$, if knowing the $\mathrm{pH}$ of the bleach solution.

Finally, the equilibrium concentration of chlorinated species in PE is given by the usual Henry's law:

$\left[\mathrm{ClO}_{2}\right]_{\mathrm{S}}=\mathrm{S} \times \mathrm{p}=\left[\mathrm{ClO}_{2}\right]_{\mathrm{S} 0} \exp \left(-\frac{\mathrm{H}_{\mathrm{C}}}{\mathrm{RT}}\right)$

with $\left[\mathrm{ClO}_{2}\right]_{\mathrm{S} 0}=1.8 \times 10^{-4}\left(1-\mathrm{X}_{\mathrm{C}}\right)\left[\mathrm{ClO}_{2}\right]_{\mathrm{W}} \mathrm{mol} . \mathrm{L}^{-1}$ and $\mathrm{H}_{\mathrm{C}}=4450 \mathrm{~J} \mathrm{~mol}^{-1}$

$\left[\mathrm{Cl}_{2}\right]_{\mathrm{S}}=\mathrm{S} \times \mathrm{p}=\left[\mathrm{Cl}_{2}\right]_{\mathrm{s} 0} \exp \left(-\frac{\mathrm{H}_{\mathrm{C}}}{\mathrm{RT}}\right)$

with $\left[\mathrm{Cl}_{2}\right]_{\mathrm{S} 0}=4.7 \times 10^{2}\left(1-\mathrm{X}_{\mathrm{C}}\right)\left[\mathrm{Cl}_{2}\right]_{\mathrm{W}}$ mol. $\mathrm{L}^{-1}$ and $\mathrm{H}_{\mathrm{C}}=19130 \mathrm{~J} \mathrm{~mol}^{-1}$

For a PE sample of $\mathrm{X}_{\mathrm{C}}=50 \%$ immerged in a water solution regulated at $\left[\mathrm{ClO}_{2}\right]_{\mathrm{W}}=100 \mathrm{ppm}$, it comes

$\left[\mathrm{ClO}_{2}\right]_{\mathrm{S}}=1.5 \times 10^{-3} \mathrm{~mol} 1^{-1}$ at $25^{\circ} \mathrm{C}$

$\left[\mathrm{ClO}_{2}\right]_{\mathrm{S}}=1.8 \times 10^{-3} \mathrm{~mol} 1^{-1}$ at $60{ }^{\circ} \mathrm{C}$

Thus, in the temperature interval of practical interest, $\left[\mathrm{ClO}_{2}\right]_{\mathrm{S}}$ would keep the same order of magnitude. The same conclusion can be made for $\left[\mathrm{Cl}_{2}\right]_{\mathrm{s}}$.

It appears clearly that $\mathrm{Cl}_{2}$ is considerably more soluble in $\mathrm{PE}$ than $\mathrm{ClO}_{2}$, but its equilibrium concentration depends mainly on the pH value. As an example, for a PE sample of $\mathrm{X}_{\mathrm{C}}=50 \%$ immersed in a bleach solution regulated at $[\mathrm{Cl} \text { free }]_{\mathrm{W}}=100 \mathrm{ppm}$ and $\mathrm{T}=60{ }^{\circ} \mathrm{C}$, it comes:

$\left[\mathrm{Cl}_{2}\right]_{\mathrm{s}}=2.8 \mathrm{~mol} \mathrm{l}^{-1}$ at $\mathrm{pH}=4$

$\left[\mathrm{Cl}_{2}\right]_{\mathrm{S}}=3.2 \times 10^{-1} \mathrm{~mol} \mathrm{l}^{-1}$ at $\mathrm{pH}=5$ 
$\left[\mathrm{Cl}_{2}\right]_{\mathrm{S}}=2.2 \times 10^{-3} \mathrm{~mol} \mathrm{1}^{-1}$ at $\mathrm{pH}=7$

\section{Appendix C. Kinetic model for predicting PE oxidation in a hydrogen peroxide solution}

The mechanistic scheme describing the radical chain oxidation of additive free PE in a hydrogen peroxide solution can be summarized as follows. It is composed of five main stages:

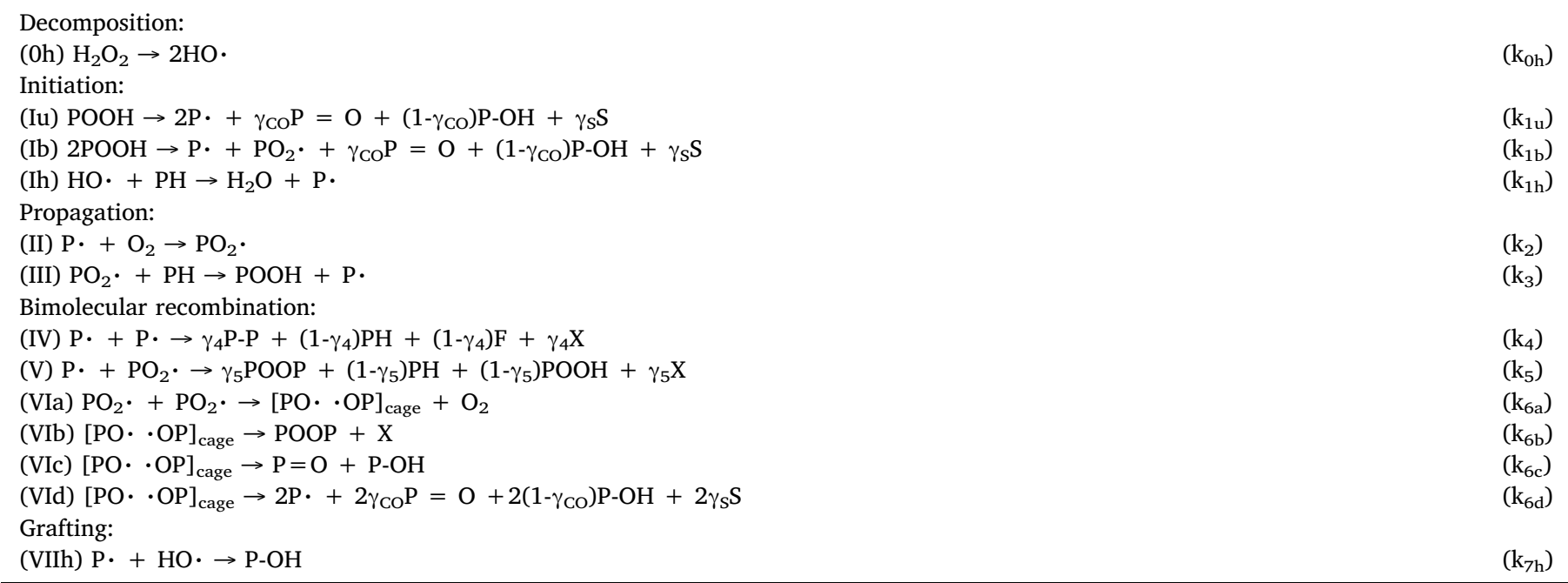

in which $\mathrm{H}_{2} \mathrm{O}_{2}$ accounts for hydrogen peroxide having penetrated into the PE matrix.

A kinetic model was derived from this mechanistic scheme by applying the classical rules of the chemical kinetics. It is composed of 9 non-linear differential equations:

$\frac{\mathrm{d}\left[\mathrm{H}_{2} \mathrm{O}_{2}\right]}{\mathrm{dt}}=-\mathrm{k}_{0 \mathrm{~h}}\left[\mathrm{H}_{2} \mathrm{O}_{2}\right]+\mathrm{D}_{\mathrm{H}_{2} \mathrm{O}_{2}} \frac{\partial^{2}\left[\mathrm{H}_{2} \mathrm{O}_{2}\right]}{\partial \mathrm{z}^{2}}$

$\frac{\mathrm{d}\left[\mathrm{HO}^{*}\right]}{\mathrm{dt}}=2 \mathrm{k}_{0 \mathrm{~h}}\left[\mathrm{H}_{2} \mathrm{O}_{2}\right]-\mathrm{k}_{1 \mathrm{~h}}\left[\mathrm{HO}^{*}\right][\mathrm{PH}]-\mathrm{k}_{7 \mathrm{~h}}\left[\mathrm{HO}^{*}\right]\left[\mathrm{P}^{*}\right]+\mathrm{D}_{\mathrm{HO}^{*}} \frac{\partial^{2}\left[\mathrm{HO}^{*}\right]}{\partial \mathrm{z}^{2}}$

$\frac{\mathrm{d}[\mathrm{POOH}]}{\mathrm{dt}}=-\mathrm{k}_{1 \mathrm{u}}[\mathrm{POOH}]-2 \mathrm{k}_{1 \mathrm{~b}}[\mathrm{POOH}]^{2}+\mathrm{k}_{3}\left[\mathrm{PO}_{2}^{*}\right][\mathrm{PH}]+\left(1-\gamma_{5}\right) \mathrm{k}_{5}\left[\mathrm{P}^{\cdot}\right]\left[\mathrm{PO}_{2}^{*}\right]$

$\frac{\mathrm{d}\left[\mathrm{P}^{\bullet}\right]}{\mathrm{dt}}=2 \mathrm{k}_{1 \mathrm{u}} \mathrm{f}_{\mathrm{PH}}[\mathrm{POOH}]+\mathrm{k}_{1 \mathrm{~b}} \mathrm{f}_{\mathrm{PH}}[\mathrm{POOH}]^{2}+\mathrm{k}_{\mathrm{lh}}[\mathrm{HO} \cdot][\mathrm{PH}]-\mathrm{k}_{2}\left[\mathrm{O}_{2}\right]\left[\mathrm{P}^{\bullet}\right]$

$+\mathrm{k}_{3}\left[\mathrm{PO}_{2}^{*}\right][\mathrm{PH}]-2 \mathrm{k}_{4}\left[\mathrm{P}^{\cdot}\right]^{2}-\mathrm{k}_{5} \mathrm{f}_{\mathrm{PH}}\left[\mathrm{P}^{\cdot}\right]\left[\mathrm{PO}_{2}^{*}\right]+2 \mathrm{k}_{6 \mathrm{~d}} \mathrm{f}_{\mathrm{PH}}[\mathrm{PO} \cdot \mathrm{OP}]_{\text {cage }}$

$-\mathrm{k}_{7 \mathrm{~h}}\left[\mathrm{HO}^{*}\right]\left[\mathrm{P}^{\cdot}\right]$

$\frac{\mathrm{d}\left[\mathrm{PO}_{2}^{*}\right]}{\mathrm{dt}}=\mathrm{k}_{1 \mathrm{~b}} \mathrm{f}_{\mathrm{PH}}[\mathrm{POOH}]^{2}+\mathrm{k}_{2}\left[\mathrm{O}_{2}\right]\left[\mathrm{P}^{\bullet}\right]-\mathrm{k}_{3}\left[\mathrm{PO}_{2}^{*}\right][\mathrm{PH}]-\mathrm{k}_{5} \mathrm{f}_{\mathrm{PH}}\left[\mathrm{P}^{\bullet}\right]\left[\mathrm{PO}_{2}^{*}\right]$

$-2 \mathrm{k}_{6 \mathrm{a}}\left[\mathrm{PO}_{2}^{*}\right]^{2}$

$\frac{\mathrm{d}[\mathrm{PO} \cdot \mathrm{OP}]_{\text {cage }}}{\mathrm{dt}}=\mathrm{k}_{6 \mathrm{a}}\left[\mathrm{PO}_{2}^{*}\right]^{2}-\left(\mathrm{k}_{6 \mathrm{~b}}+\mathrm{k}_{6 \mathrm{c}}+\mathrm{k}_{6 \mathrm{~d}} \mathrm{f}_{\mathrm{PH}}\right)[\mathrm{PO} \cdot \mathrm{OP}]_{\text {cage }}$

$\frac{\mathrm{d}[\mathrm{PH}]}{\mathrm{dt}}=-\left(2+\gamma_{\mathrm{S}}\right) \mathrm{k}_{1 \mathrm{u}} \mathrm{f}_{\mathrm{PH}}[\mathrm{POOH}]-\left(1+\gamma_{\mathrm{S}}\right) \mathrm{k}_{1 \mathrm{~b}} \mathrm{f}_{\mathrm{PH}}[\mathrm{POOH}]^{2}-\mathrm{k}_{1 \mathrm{~h}}[\mathrm{HO} \cdot][\mathrm{PH}]$

$-\mathrm{k}_{3}\left[\mathrm{PO}_{2}^{*}\right][\mathrm{PH}]-\left(1-\gamma_{5}\right) \mathrm{k}_{5} \mathrm{f}_{\mathrm{PH}}\left[\mathrm{P}^{\cdot}\right]\left[\mathrm{PO}_{2}^{*}\right]-2\left(1+\gamma_{\mathrm{S}}\right) \mathrm{k}_{6 \mathrm{~d}} \mathrm{f}_{\mathrm{PH}}[\mathrm{PO} \cdot \mathrm{OP}]_{\text {cage }}$

$-\mathrm{k}_{7 \mathrm{~h}}\left[\mathrm{HO}^{\bullet}\right]\left[\mathrm{P}^{\cdot}\right]$

$\frac{\mathrm{d}\left[\mathrm{O}_{2}\right]}{\mathrm{dt}}=-\mathrm{k}_{2}\left[\mathrm{O}_{2}\right]\left[\mathrm{P}^{\cdot}\right]+\mathrm{k}_{6 \mathrm{a}}\left[\mathrm{PO}_{2}^{*}\right]^{2}+\mathrm{D}_{\mathrm{O}_{2}} \frac{\partial^{2}\left[\mathrm{O}_{2}\right]}{\partial \mathrm{z}^{2}}$

$\frac{\mathrm{d}[\mathrm{P}=\mathrm{O}]}{\mathrm{dt}}=\gamma_{\mathrm{CO}} \mathrm{k}_{1 \mathrm{u}} \mathrm{f}_{\mathrm{PH}}[\mathrm{POOH}]+\gamma_{\mathrm{CO}} \mathrm{k}_{1 \mathrm{~b}} \mathrm{f}_{\mathrm{PH}}[\mathrm{POOH}]^{2}+\mathrm{k}_{6 \mathrm{c}}[\mathrm{PO} \cdot \mathrm{OP}]_{\text {cage }}$

$+2 \gamma_{\mathrm{CO}} \mathrm{k}_{6 \mathrm{~d}} \mathrm{f}_{\mathrm{PH}}[\mathrm{PO} \cdot \cdot \mathrm{OP}]_{\text {cage }}$

where $\mathrm{z}$ is the depth beneath the sample surface and $\mathrm{D}_{\mathrm{H} 2 \mathrm{O} 2}, \mathrm{D}_{\mathrm{HO}}$. and $\mathrm{D}_{\mathrm{O} 2}$ are the respective diffusion coefficients of $\mathrm{H}_{2} \mathrm{O}_{2}, \mathrm{HO}^{\circ}$ and $\mathrm{O}_{2}$ in the sample 
thickness. The mathematical expression of $\mathrm{f}_{\mathrm{PH}}$ is given in Appendix A. The boundary conditions are:

a) When $\mathrm{t}=0,\left[\mathrm{H}_{2} \mathrm{O}_{2}\right]=\left[\mathrm{H}_{2} \mathrm{O}_{2}\right]_{\mathrm{s}}$ (equilibrium concentration of hydrogen peroxide) at $\mathrm{z}=0$ and $\mathrm{z}=\mathrm{L}$ (i.e at the sample surfaces, $\mathrm{L}$ being the sample thickness) and $\left[\mathrm{H}_{2} \mathrm{O}_{2}\right]=0$ everywhere else.

b) When $\mathrm{t}=0,[\mathrm{HO} \cdot]=[\mathrm{P} \cdot]=\left[\mathrm{PO}_{2} \cdot\right]=[\mathrm{PO} \cdot \cdot \mathrm{OP}]_{\text {cage }}=[\mathrm{P}=\mathrm{O}]=0,[\mathrm{POOH}]=[\mathrm{POOH}]_{0}=10^{-2} \mathrm{~mol}^{-1},[\mathrm{PH}]=[\mathrm{PH}]_{0}=60 \mathrm{~mol} 1^{-1}$ (initial concentration in methylene groups), and $\left[\mathrm{O}_{2}\right]=\left[\mathrm{O}_{2}\right]_{\mathrm{S}}=3.810^{-4} \mathrm{~mol} \mathrm{l}^{-1}$ (equilibrium concentration of oxygen) at every z. c) When $\mathrm{t}>0,\left[\mathrm{O}_{2}\right]=\left[\mathrm{O}_{2}\right]_{\mathrm{S}}=3.810^{-4} \mathrm{~mol} \mathrm{l}^{-1},\left[\mathrm{H}_{2} \mathrm{O}_{2}\right]=\left[\mathrm{H}_{2} \mathrm{O}_{2}\right]_{\mathrm{S}}$ at $\mathrm{z}=0$ and $\mathrm{z}=\mathrm{L}$.

The numerical methods for solving such a system of differential equations, then deducing the average concentrations of all chemical species over the entire sample thickness, are indicated in Appendix A.

\section{References}

[1] M. Ifwarson, Life-time of polyethylene pipes under pressure and exposure to high temperatures, Kunstst. Ger. Plast. 79 (6) (1989) 20-22.

[2] Y. Lu, N. Brown, The ductile-brittle transition in a polyethylene copolymer, J. Mater Sci. 25 (1) (1990) 29-34.

[3] H.-H. Kausch, Polymer Fracture, second ed., Springer-Verlag, Berlin, 1987.

[4] P.G. De Gennes, Reptation of a polymer chain in the presence of fixed obstacles, J Chem Phys Am. Inst. Phys. 55 (2) (1971) 572.

[5] A. Lustiger, R.L. Markham, Importance of tie molecules in preventing polyethylene fracture under long-term loading conditions, Polymer 24 (12) (1983) 1647-1654.

[6] Y.L. Huang, N. Brown, Dependence of slow crack growth in polyethylene on butyl branch density: morphology and theory, J. Polym. Sci. B Polym. Phys. 29 (1) (1991) 129-137.

[7] N. Brown, X. Lu, Y.-L. Huang, R. Qian, Slow crack growth in polyethylene - a review, Makromol. Chem. Macromol. Symp. 41 (1) (1991) 55-67.

[8] T. Trankner, M.S. Hedenqvist, U.W. Gedde, Molecular and lamellar structure of an extrusion-grade medium-density polyethylene for gas distribution, Polym. Eng. Sci. 34 (21) (1994) 1581-1588.

[9] M.S. Hedenqvist, Morphology and Morphology Sensitive Properties of Polyethylene: Fracture Behavior and Diffusivity, PhD thesis Department of Polymer Technology, Royal Institute of Technology, Stockholm, 1995.

[10] U.W. Gedde, J.F. Jansson, G. Liljenström, S. Eklund, S.R. Holding, P.-L. Wang, P.E. Werner, Molecular structure, crystallization behavior, and morphology of fractions obtained from an extrusion grade high-density polyethylene, Polym. Eng. Sci. 28 (20) (1988) 1289-1303.

[11] A.J. Peacock, Handbook of Polyethylene. Structures, Properties and Applications, Marcel Dekker, Inc., New York, 2000.

[12] X. Colin, L. Audouin, J. Verdu, M. Rozental-Evesque, B. Rabaud, F. Martin, F. Bourgine, Aging of polyethylene pipes transporting drinking water disinfected by chlorine dioxide. I- Chemical aspects, Polym. Eng. Sci. 49 (7) (2009) 1429-1437.

[13] X. Colin, L. Audouin, J. Verdu, M. Rozental-Evesque, B. Rabaud, F. Martin, F. Bourgine, Aging of polyethylene pipes transporting drinking water disinfected by chlorine dioxide. I- Lifetime prediction, Polym. Eng. Sci. 49 (8) (2009) 1642-1652.

[14] W. Yu, B. Azhdar, D. Andersson, T. Reitberger, J. Hassinen, T. Hjertberg, U.W. Gedde, Deterioration of polyethylene pipes exposed to water containing chlorine dioxide, Polym. Degrad. Stab. 96 (5) (2001) 790-797.

[15] S.W. Bradley, W.L. Bradley, The effect of chlorine on the long-term durability of crosslinked polyethylene pipe, Proceedings $10^{\text {th }}$ International Conference on Deformation, Yield and Fracture of Polymers, Cambridge, UK, 1997, pp. 114-117.

[16] M. Ifwarson, K. Aoyama, Results and experiences from tests on polyolefin pipes exposed to chlorinated water, Proceedings Plastic Pipes X Conference, Gothenburg, 1998, pp. 691-701.

[17] T.S. Gill, R.J. Knapp, S.W. Bradley, W.L. Bradley, Long-term durability of crosslinked polyethylene tubing used in chlorinated hot water systems, Plast. Rubb Compos 28 (6) (1999) 309-313.

[18] J.P. Dear, N.S. Mason, The effects of chlorine depletion of antioxidants in polyethylene, Polym. Polym. Compos 9 (1) (2001) 1-13.

[19] J. Hassinen, M. Lundback, M. Ifwarson, U.W. Gedde, Deterioration of polyethylene pipes exposed to chlorinated water, Polym. Degrad. Stab. 84 (2) (2004) 261-267.

[20] J.P. Dear, N.S. Mason, Effect of chlorine on polyethylene pipes in water distribution networks, J. Mater Des. App 220 (3) (2006) 97-111.

[21] X. Colin, J. Verdu, B. Rabaud, Stabiliser thickness profiles in polyethylene pipes transporting drinking water disinfected by bleach, Polym. Eng. Sci. 51 (8) (2011) 1541-1549.

[22] D.A.S. Ravens, The Chemical reactivity of poly(ethyelene terephthalate). Heterogeneous hydrolysis by hydrochloric acid, Polymer 1 (1960) 375-383.

[23] D.W. Van Krevelen, K.J. Te Nijenhuis, Properties of Polymers. Their Estimation and Correlation with Chemical Structure. Their Numerical Estimation and Prediction from Additive Group Contributions, fourth ed., Elsevier, Amsterdam, 2009.

[24] G. Durliat, L'eau de javel: Sa chimie et son action biochimique, Bull. Union Phys. 91 (792) (1997) 451-471.

[25] R.E. Connick, Y.-T. Chia, The hydrolysis of chlorine and its variation with temperature, J. Amer Chem. Soc. 81 (6) (1959) 1280-1284.

[26] J.C. Morris, The acid ionization constant of $\mathrm{HOCl}$ from 5 to $35^{\circ} \mathrm{C}$, J. Phys. Chem. 70 (1966) 3798-3805.

[27] G. Holst, The chemistry of bleaching and oxidizing agents, Chem. Rev. 54 (1954) 169-194.
[28] S. Khatua, Y.-L. Hsieh, Chlorine degradation of polyether-based polyurethane, J. Polym. Sci. A Polym. Chem. 35 (1997) 3263-3273.

[29] S. Rouaix, C. Causserand, P. Aimar, Experimental study of the effects of hypochlorite on polysulfone membrane properties, J. Membr. Sci. 277 (2006) 137-147.

[30] C. Causserand, S. Rouaix, J.-P. Lafaille, P. Aimar, Ageing of polysulfones membranes in contact with bleach solution: role of radical oxidation and of some dissolved metal ions, Chem. Eng. Process 47 (2008) 48-56.

[31] E. Gaudichet-Maurin, F. Thominette, Ageing of polysulfone ultrafitration membranes in contact with bleach solutions, J. Membr. Sci. 282 (2006) 198-204.

[32] J.A. Epstein, M. Lewin, Kinetics of the oxidation of cotton with hypochlorite in the pH range 5-10, J. Polym. Sci. 58 (1962) 991-1008.

[33] K. Fukatsu, S. Kokot, Degradation of poly(ethylene oxide) by electro-generated active species in aqueous halide medium, Polym. Degrad. Stab. 72 (2) (2001) 353-359.

[34] J.C. Calvert, J.N. Pitts, Photochemistry, John Wiley \& Sons, Inc., New York, 1966, pp. 824-826.

[35] D.W. McCall, D.C. Douglass, L.L. Blyler Jr., G.E. Johnsson, L.W. Jelinski, H.E. Bair Solubility and diffusion of water in low-density polyethylene, Macromol 17 (9) (1984) 1644-1649.

[36] B. Hickel, Absorption spectra and kinetics of methyl and ethyl radicals in water, J Phys. Chem. 79 (11) (1975) 1054-1059.

[37] E.S. Rudakov, L.K. Volkova, V.P. Tretyakov, Low selectivity of reactions of $\mathrm{OH}$ radicals with alkanes in aqueous solution, React. Kinet. Catal. Lett. 16 (4) (1981) 333-337.

[38] N. Getoff, Advancements of radiation induced degradation of pollutants in drinking and waste water, Int. J. Radiat. App Instrum. A Appl. Radiat. Isot. 40 (7) (1989) 585-594.

[39] L. Audouin, V. Langloi, J. Verdu, J.C.M. De Bruijn, Role of oxygen diffusion in polymer ageing: kinetic and mechanical aspects, J. Mater Sci. 29 (3) (1994) 569-583.

[40] M. Da Cruz, L. Van Schoors, K. Benzarti, X. Colin, Thermo-oxidative degradation of additive free polyethylene. Part I. Analysis of chemical modifications at molecular and macromolecular scales, J. Appl. Polym. Sci. 133 (18) (2016) 43287.

[41] S. Al-Malaika, S. Chohan, M. Coker, G. Scott, R. Arnaud, P. Dabin, A. Fauve, J. Lemaire, A comparative study of the degradability and recyclability of different classes of degradable polyethylene, in: A.-C. Albertsson, S.J. Huang (Eds.), Degradable Polymers, Recycling and Plastics Waste Management, Marcel Dekker, Inc., New York, 1995, pp. 117-138 Chap. 12.

[42] B.H. Stuart, Infrared Spectroscopy: Fundamentals and Applications, Analytical Techniques in the Science Series, John Wiley \& Sons, Ltd, Chichester, 2004.

[43] A.W. Johnson, Invitation à la chimie organique, Editions De Boeck Université, Paris, 2002.

[44] F. Bueche, Viscosity, self-diffusion and allied effects in solid polymers, J. Chem. Phys. 20 (12) (1952) 1959-1964.

[45] F. Bueche, The viscoelastic properties of plastics, J. Chem. Phys. 22 (4) (1954) 603-609.

[46] N. Khelidj, X. Colin, L. Audouin, J. Verdu, C. Monchy-Leroy, V. Prunier, Oxidation of polyethylene under irradiation at low temperature and low dose rate. Part I- the case of "pure" radiochemical initiation, Polym. Degrad. Stab. 91 (7) (2006) 1593-1597.

[47] N. Khelidj, X. Colin, L. Audouin, J. Verdu, C. Monchy-Leroy, V. Prunier, Oxidation of polyethylene under irradiation at low temperature and low dose rate. Part II- Low temperature thermal oxidation, Polym. Degrad. Stab. 91 (7) (2006) 1598-1605.

[48] X. Colin, C. Monchy-Leroy, L. Audouin, J. Verdu, Lifetime prediction of polyethylene in nuclear plants, Nucl. Instrum. Methods Phys. Res. Sec B 265 (1) (2007) $251-255$.

[49] N.R. Greiner, Hydroxyl radical kinetics by kinetic spectroscopy. VI. Reactions with alkanes in the range $300-500^{\circ} \mathrm{K}, \mathrm{J}$. Chem. Phys. 53 (1970) 1070-1076.

[50] X. Colin, L. Audouin, J. Verdu, Determination of thermal oxidation rate constants by an inverse method. Application to polyethylene, Polym. Degrad. Stab. 86 (2004) $309-321$.

[51] E. Hairer, G. Wanner, Solving Ordinary Differential Equations II. Stiff and Differential-algebraic Problems, Springer, Berlin, 1991.

[52] G.J. Van Amerongen, Diffusion in elastomers, Rubb Chem. Technol. 37 (1964) 1065-1153.

[53] A.S. Michaels, H.J. Bixler, Solubility of gases in polyethylene, J. Polym. Sci. 50 (1961) 393-412.

[54] A.S. Michaels, H.J. Bixler, Flow of gases through polyethylene, J. Polym. Sci. 50 (1961) 413-439. 
[55] W.J. Masschelein, Le dioxyde de chlore pour la maîtrise de la qualité des eaux, La Trib. l'Eau 54 (2011) 613-614.

[56] IRSN, Dioxyde de chlore, Toxicological sheet 258, (2011).

[57] Lutz-Jesco GmbH, Chlorine, Physical Data Sheet SD 20102

[58] IRSN, Chlore, Toxicological Sheet 51, (2008).

[59] G. Moad, I.J. Dagley, J. Habsuda, C.J. Garvey, G. Li, L. Nichols, G.P. Simon, M.R. Nobile, Aqueous hydrogen peroxide-induced degradation of polyolefins: greener process for controlled-rheology polypropylene, Polym. Degrad. Stab. 117 (2015) 97-108

[60] Colin X. Non-empirical kinetic modelling of non-Fickian water absorption induced by a chemical reaction in epoxy-amine networks. In: Davies P, Rajapakse YDS editors. Solid Mechanics and its Applications: Durability of Composites in a Marine Environment, Vol 2. Dordrecht: Springer, in press.

[61] S. Radl, S. Larisegger, D. Suzzi, J.G. Khinast, Quantifying absorption effects during hydrogen peroxide decontamination, J. Pharm. Innov. 6 (2011) 202-216.

[62] O. Saito, On the effects of high energy radiation to polymers. I. Crosslinking and degradation, J. Phys. Soc. Jpn. 13 (2) (1958) 198-206.

[63] O. Saito, On the effects of high energy radiation to polymers. II. End-linking and gel fraction, J. Phys. Soc. Jpn. 13 (12) (1958) 1451-1464. 